\title{
The Molecular Basis of Ubiquitin-Conjugating Enzymes (E2s) as a Potential Target for Cancer Therapy
}

\author{
Xiaodi Du, Hongyu Song, Nengxing Shen, Ruiqi Hua and Guangyou Yang * $\mathbb{D}$ \\ Department of Parasitology, College of Veterinary Medicine, Sichuan Agricultural University, \\ Chengdu 611130, China; 2019203033@stu.sicau.edu.cn (X.D.); songhongyu95@outlook.com (H.S.); \\ shennengxing@stu.sicau.edu.cn (N.S.); ruiqihua@stu.sicau.edu.cn (R.H.) \\ * Correspondence: guangyou1963@aliyun.com
}

check for updates

Citation: Du, X.; Song, H.; Shen, N.; Hua, R.; Yang, G. The Molecular Basis of Ubiquitin-Conjugating Enzymes (E2s) as a Potential Target for Cancer Therapy. Int. J. Mol. Sci. 2021, 22, 3440. https://doi.org/10.3390/ ijms22073440

Academic Editor: Daniela Taverna

Received: 27 February 2021

Accepted: 23 March 2021

Published: 26 March 2021

Publisher's Note: MDPI stays neutral with regard to jurisdictional claims in published maps and institutional affiliations.

Copyright: (c) 2021 by the authors. Licensee MDPI, Basel, Switzerland. This article is an open access article distributed under the terms and conditions of the Creative Commons Attribution (CC BY) license (https:// creativecommons.org/licenses/by/ $4.0 /)$.

\begin{abstract}
Ubiquitin-conjugating enzymes (E2s) are one of the three enzymes required by the ubiquitinproteasome pathway to connect activated ubiquitin to target proteins via ubiquitin ligases. E2s determine the connection type of the ubiquitin chains, and different types of ubiquitin chains regulate the stability and activity of substrate proteins. Thus, E2s participate in the regulation of a variety of biological processes. In recent years, the importance of E2s in human health and diseases has been particularly emphasized. Studies have shown that E2s are dysregulated in variety of cancers, thus it might be a potential therapeutic target. However, the molecular basis of E2s as a therapeutic target has not been described systematically. We reviewed this issue from the perspective of the special position and role of E2s in the ubiquitin-proteasome pathway, the structure of E2s and biological processes they are involved in. In addition, the inhibitors and microRNAs targeting E2s are also summarized. This article not only provides a direction for the development of effective drugs but also lays a foundation for further study on this enzyme in the future.
\end{abstract}

Keywords: ubiquitin-conjugating enzymes; E2s; cancer; target; NF-кB; inhibitors

\section{Introduction}

The 2004 Nobel Prize in Chemistry was awarded to three scientists (Aron Ciechanover, Avaram Heshko and Irwin Rose) for their discovery of the mechanism of protein degradation regulated by ubiquitin $(\mathrm{Ub})$. They found the same class of peptides in mammals, bacteria and plants, whose structures and properties were very similar. They named it $\mathrm{Ub}$ because of its widespread existence [1]. Ub has the property of forming stable chemical bonds with other proteins to regulate their stability, activity or position [2]. Ub modifies substrate proteins through the ubiquitin-proteasome pathway (UPP), which requires three key enzymes-Ubiquitin-activating enzyme (E1), ubiquitin-conjugating enzyme (E2), and ubiquitin ligase (E3), to hydrolyze the target proteins of ubiquitination in cells to maintain protein homeostasis [3].

Residing at the center of the cascade, E2s largely determine Ub chain topology and are responsible for recruiting E3 ligases and their substrates [4]. The relationship between E2s and human cancer has been studied extensively. Ullah et al. [5] showed that increased expression or mutation of $U B E 2 O$ is common in breast cancer (BC), gastric cancer (GC), renal carcinoma (RC) and ovarian cancer (OC). The UBE2C mRNA or protein can hardly be detected in normal tissues; however, it is abnormally elevated in diseases such as cerebral cancer, lung cancer (LC), leukemia, lymphoma, GC, BC, colon cancer (CC) and hepatocellular carcinoma (HCC) [6-9]. Even UBE2C transgenic mice are more likely to develop spontaneous tumors and tumors induced by carcinogens [10]. Wu et al. [11] found that UBE2N is related to the low overall survival rate of human BC and is directly involved in the process of metastasis, which is necessary for lung colonization and the survival and proliferation of established metastatic lesions. Cases of the abnormal expression of other E2 members in different cancer cells or tissues are also widespread. This not only 
affects the protein turnover of cancer cells, but also indirectly regulates the proliferation, metastasis, anti-apoptosis and drug resistance of cancer cells by participating in certain biological processes. Although researchers are committed to studying the roles of E2s in various diseases and constantly emphasize the potential of E2s as a therapeutic target, the molecular basis of E2s as a potential therapeutic target for cancer has not been described systematically. A newly published review classified systematically all the reported small molecular inhibitors of the basic components of UPP, including E1, E2, E3, 20s proteasome catalytic core particles and 19s proteasome catalytic core particles, as well as their mechanisms of action and limitations [12]; however, the inhibitors and microRNAs (miRNAs) targeting E2s were not fully summarized. Therefore, we reviewed the literature in the past five years to cover these two aspects. We discuss the molecular basis of E2s as a target for cancer therapy from the special position and functions of E2s in UPP, the structure of E2s and biological processes they are participated in, and the efforts made to develop corresponding inhibitors. Researchers can select E2 as a specific target and consider the possible positive and negative effects according to the biological processes it participates in, allowing them to develop effective inhibitors with few side effects to control the occurrence and development of cancer.

\section{The Position of E2 in UPP}

The UPP comprises Ub, E1, E2, E3, 26S proteasome, deubiquitinating enzymes (DUBs) and target proteins [13]. It exists widely in eukaryotes as well as in prokaryotes, and is an important pathway for selective protein degradation in organisms. The UPP involves two consecutive processes: The ubiquitination system ubiquitinates the substrate proteins and $26 \mathrm{~S}$ proteasome degrades ubiquitinated target proteins [14]. First, under the energy supply of adenosine-triphosphate (ATP), the C-glycine residue of Ub forms a high energy thioester bond with the cysteine residue of E1. Later, E1 connects the activated Ub to E2 through the intermediate product of $\mathrm{Ub}$ adenylation to form the E2-Ub sulfhydryl ester. Although $\mathrm{Ub}$ can be transferred directly or indirectly from E2 to the substrate, E3 is usually needed to identify specific substrates. Through a E3 enzyme, $\mathrm{Ub}$ is transferred from the thioester intermediate to the $\varepsilon$ amino group of the target protein (lysine residue) to form an isopeptide bond and then subsequently activates the $\mathrm{Ub}$ to connect the 48th lysine residue of the previous $\mathrm{Ub}$ molecule to form a signal. This polyubiquitin (polyUb) chain is recognized and degraded by proteasome $[15,16]$ (Figure 1).

E2 are multi-functional enzymes that primarily engage in two types of reactions with a simple active site in the UPP: (1) Transthiolation (transfer from a thioester to a thiol group) and (2) Aminolysis (transfer from a thioester to an amino group). Most E2s can interact with E1 and one or more E3s [17], providing a binding platform for E1, E3, and activated $\mathrm{Ub} / \mathrm{Ub}$-like $(\mathrm{Ubl})$. Some E2s also play a role outside the traditional $\mathrm{Ub}$ transport pathway by regulating the activity of other enzymes [18]. It should be pointed out that Ub contains seven different lysine residues (Lys6, Lys11, Lys27, Lys29, Lys33, Lys48, and Lys63), any of which can be covalently linked with other Ub molecules. Besides, the $\mathrm{N}$-terminal (N-) methionine (M1) of $\mathrm{Ub}$ is also a site for covalent binding of other Ubs to form M1-linked linear ubiquitylation [19]. So, the type of these Ub chains and the fate of substrate proteins are determined by E2s. PolyUbs can be formed through the same $\mathrm{Ub}$ linkage (homotypic chains) or a combination of different lysine linkages, resulting in mixed or branched structures (heterotypic chains). It is only through recognition of these different $\mathrm{Ub}$ structures by $\mathrm{Ub}$-binding proteins (UBPs) that the intracellular fate of the protein is determined [20]. A branched Lys11/Lys48 chain in heterotypic chains is considered to be a better signal for proteasome degradation [21]. Generally speaking, Lys48 and Lys11 chains are further involved in proteasome degradation. Proteasome shuttling factors preferentially bind Lys 48 chains compared with Lys11 chains. M1-linked ubiquitin chains, Lys63 and Lys6 chains are usually involved in non-proteolytic processes, such as immune homoeostasis [22], DNA repair, signal transduction, and endosomal-lysosomal degradation [23]. The Lys11 chain is less studied than the Lys48 or Lys63 chain, but it seems 
to serve as a degradation signal for anaphase-promoting complex/cyclosome (APC/C) substrates in the regulation of cell division [24]. The functions of other connection types of $\mathrm{Ub}$ chains are not entirely clear.

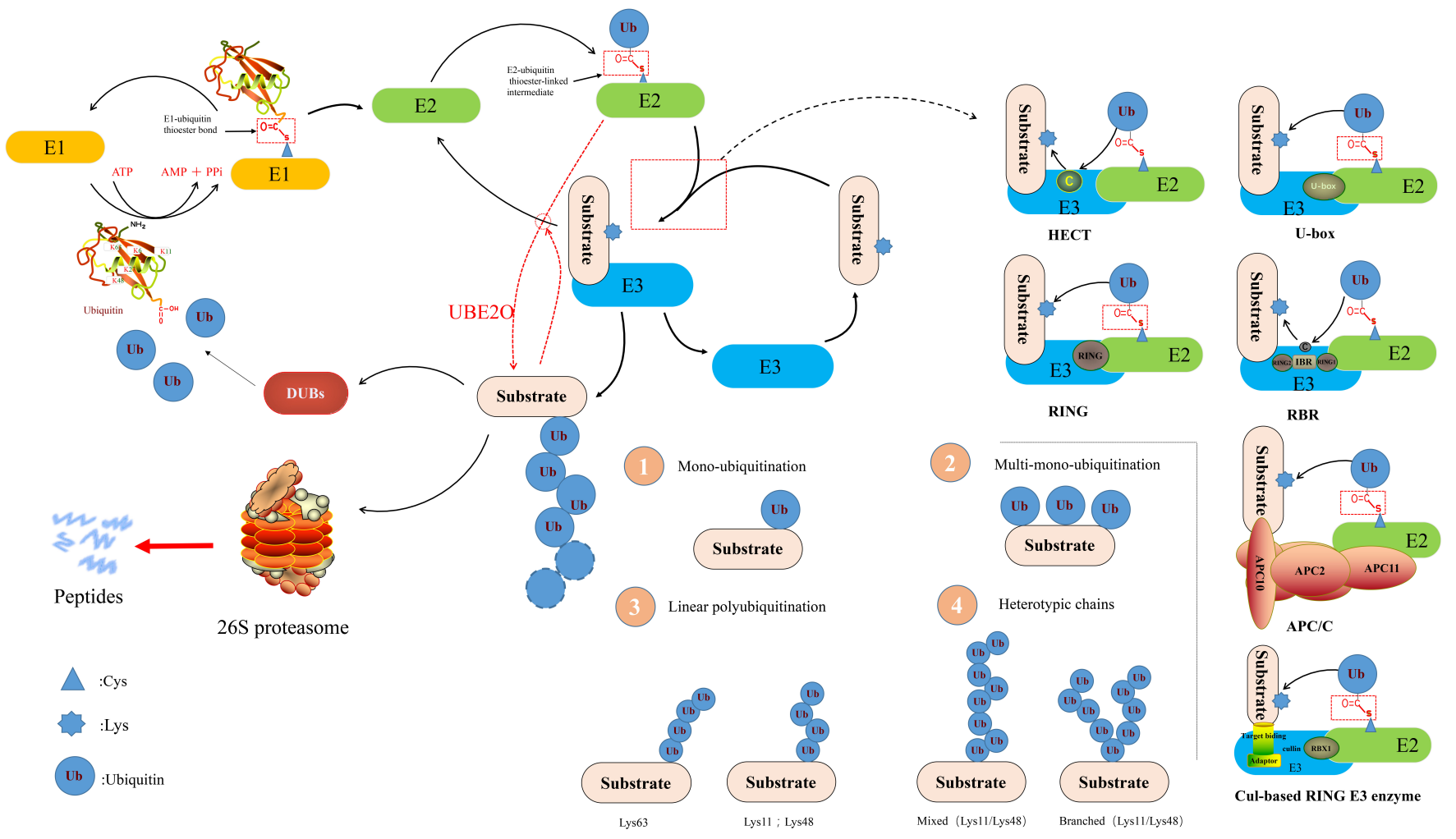

Figure 1. A schematic diagram of the ubiquitin-proteasome pathway (refer to [13]). Ubiquitin (Ub) is activated by ubiquitin-activating enzyme in an adenosine-triphosphate-dependent manner. Ubiquitin-activating enzyme hydrolyzes adenosine-triphosphate and forms a complex with $\mathrm{Ub}$. Subsequently, $\mathrm{Ub}$ is transferred to one of many different E2s. In some reactions, E2 (UBE2O) can directly ubiquitinate the substrate, while others need the help of ubiquitin ligases (E3s). E3s are currently categorized into three families, (i) Homologous to E6-associated Protein C-terminus (HECT), (ii) Really Interesting New Gene (RING), and (iii) U-box Domain [25]. The Cullin-RING ligases (CRLs), APC/C ligase, and RING-Between-RING ligases (RBRs) all belong to RING E3s. Ubiquitination of substrates occur as mentioned in the three ways: Monoubiquitination, multi-monoubiquitination, and polyubiquitination (including linear polyubiquitination and branched polyubiquitination).

\section{The Structure and Classification of E2}

To date, $1635 \mathrm{E} 2 \mathrm{~s}$ have been identified in eukaryotic genomes and about $40 \mathrm{E} 2 \mathrm{~s}$ in human have been identified to be involved in the transfer of $\mathrm{Ub} / \mathrm{Ubl}$ proteins (e.g., small ubiquitin-like modifier (SUMO) and NEDD8), while other eukaryotic genome E2 families have 16-35 members [26]. Their names consist of the designation ubiquitin enzyme E2 (UBE2) followed by a serial capital letter according to their consecutive discovery. Most E2s have a highly conserved ubiquitin-conjugating region comprising 150-200 amino acids, known as the UBC domain, which binds Ub/Ubl proteins activated by ATP (Figure 2A). This domain adopts an $\alpha / \beta$-fold, typically with four $\alpha$-helices and a four stranded $\beta$ sheets (Figure 2B). The UBC domain is embellished with functionally important insertions, such as UBE2R1 or UBE2G2. Moreover, a few E2s have an additional structured domain linked to their UBC domain (e.g., UBE2K) or are part of large multi-domain proteins (e.g., UBE2O) [27]. Ubiquitin-conjugating enzyme variant (UEV) exhibits high similarity with E2s both in structure and amino acid sequence, but lacks the UBC domain and the activesite cysteine residue, and thus is catalytically inactive [28]. The E2 family has been divided into four classes: Class I, UBC domain only; class II, UBC domain plus an N- extension; 
class III, UBC plus a C- extension; and class IV, UBC plus both N- and C- extensions [29]. These extra domains not only create E2s of diverse molecular size, including the largest E2, BIRC6 (4857 amino acids), but also can govern intracellular localization, confer regulatory properties, and enable specific interactions with particular E3s [30]. Although the shallow and exposed nature of the catalytic site make it difficult to target the site directly with small molecules, the distinct regions in which E2s are involved in many protein-protein interactions raise the possibility of additional modes of inhibition [31].

Table 1. E2s, its synonyms, classification, relevant biological roles, and involvement in cancers.

\begin{tabular}{|c|c|c|c|c|}
\hline $\begin{array}{c}\text { Name } \\
\text { (Human) }\end{array}$ & Synonyms & Classification & Biological Roles & Relevant Cancers \\
\hline UBE2A & RAD6(A) & Class I & $\begin{array}{c}\text { Transcriptional regulation } \\
\text { DNA repair [33] } \\
\text { Regulating myeloid differentiation [34] }\end{array}$ & Chronic myeloid leukemia \\
\hline UBE2B & RAD6(B) & Class I & $\begin{array}{l}\text { Ubiquitinating H2A/B and MGMT to participate in } \\
\text { DNA repair } \\
\text { Monoubiquitinating H2B to participate in } \\
\text { transcriptional activation }\end{array}$ & $\mathrm{MM}, \mathrm{BC}$ \\
\hline UBE2C & UBCH10 & Class II & $\begin{array}{l}\text { Ubiquitinating p53 and Ki67 [35] to participate in } \\
\text { G2/M transition [36] } \\
\text { Regulating the level of phosphorylated ERK1/2 to } \\
\text { participate in cell apoptosis [42] } \\
\text { Its depletion reduced OC malignancy and reversed } \\
\text { DDP resistance via downregulating CDK1 [43] }\end{array}$ & $\begin{array}{c}\text { MM of uterus, Melanoma, } \\
\text { HCC [37], HNSCC [38], CRC } \\
\text { [39], Glioma [40], TSCC [41], } \\
\text { Cerebral cancer, LC, Leukemia, } \\
\text { Lymphoma, GC [6-9], BC, } \\
\text { Esophageal cancer, CC, } \\
\text { Endometrial carcinoma, OC }\end{array}$ \\
\hline UBE2D(1/2/3) & $\mathrm{UBCH} 5(\mathrm{a} / \mathrm{b} / \mathrm{c})$ & Class I & $\begin{array}{l}\text { Regulating the level of p53 protein [44] } \\
\text { Ubiquitinating MDM2 and CCND1 }\end{array}$ & Esophageal cancer [45], PCa \\
\hline UBE2E1 & UBCH6 & Class II & $\begin{array}{l}\text { Affects the patient's response to induction } \\
\text { chemotherapy [46] }\end{array}$ & $\begin{array}{l}\text { Acute myelogenous leukemia, } \\
\text { PCa }\end{array}$ \\
\hline UBE2E2 & UBCH8 & Class II & $\begin{array}{l}\text { Stable substrate protein with ISG15 can promote } \\
\text { cancer cell movement and invasion [47] }\end{array}$ & $\mathrm{BC}$ \\
\hline UBE2E3 & UBCH9 & Class II & $\begin{array}{c}\text { Maintaining mitochondrial homeostasis [48], } \\
\text { participating in NEDD4- } 4^{-} \text {dependent epithelial } \mathrm{Na}^{+} \\
\text {channel regulation [49] }\end{array}$ & - \\
\hline UBE2G1 & UBE2G/E217K & Class I & $\begin{array}{c}\text { Regulating inflammation and innate immune } \\
\text { response [50], ubiquitinating and degrading of } \\
\text { IKZF1 and IKZF3 [51] }\end{array}$ & Myeloma \\
\hline UBE2G2 & UBC7 & Class I & $\begin{array}{c}\text { Co-regulating immune receptor downregulation } \\
\text { mediated by human cytomegalovirus US2 with } \\
\text { TRC } 8 \text { [52] }\end{array}$ & NSCLC [53], PCa [54] \\
\hline UBE2H & UBC8/UBCH2 & Class III & $\begin{array}{c}\text { Participating in neurodevelopment }[55] \\
\text { TNF- } \alpha \text { promotes the binding of the } U B E 2 H \\
\text { promoter region to NF- } \mathrm{B} \text { [ }[56]\end{array}$ & - \\
\hline UBE2J1 & UBC6 & Class III & $\begin{array}{c}\text { It negatively regulates interferon to promote RNA } \\
\text { virus infection [57] } \\
\text { Participating in spermatogenesis and growth and } \\
\text { development }\end{array}$ & Medulloblastoma [58], PCa \\
\hline UBE2J2 & NCUBE2 & Class III & $\begin{array}{l}\text { Regulates ERAD induced by human } \\
\text { cytomegalovirus US2 through TRC8 [52] }\end{array}$ & $\mathrm{HCC}[59]$ \\
\hline UBE2K & UBCH1/E2-25k & Class III & Regulating the cell cycle & - \\
\hline UBE2L3 & UBCH7 & Class I & $\begin{array}{c}\text { Participating in DSB repair } \\
\text { Ubiquitinating p53 and p27 Kip1 to regulate the cell } \\
\text { cycle [63] } \\
\text { Regulating the NF-KB signal driven by TNF- } \alpha \text { [64], } \\
\text { Rate limiting factors and therapeutic targets of } \\
\text { LUBAC activity [65] }\end{array}$ & $\begin{array}{l}\text { HCC [60], Cervical } \\
\text { Cancer [61], NSCLC [62], } \\
\text { B-cell lymphoma }\end{array}$ \\
\hline
\end{tabular}


Table 1. Cont.

\begin{tabular}{|c|c|c|c|c|}
\hline $\begin{array}{l}\text { Name } \\
\text { (Human) }\end{array}$ & Synonyms & Classification & Biological Roles & Relevant Cancers \\
\hline UBE2N & $\mathrm{UBC} 13$ & Class I & $\begin{array}{c}\text { UBE2N-UBE2V1 complex regulates innate } \\
\text { immunity and participates in the activation of } \\
\text { NF-kB [66] } \\
\text { UBE2N-UBE2V2 ubiquitinates PCNA and H2A } \\
\text { Ubiquitinating and degrading Sirt1 and inhibiting } \\
\text { histone H4 lysine } 16 \text { acetylation [70] } \\
\text { Activating MAPKs } \\
\text { Involved in the internalization of cell surface } \\
\text { receptors }\end{array}$ & $\begin{array}{l}\text { BC, Cervical Cancer [67], } \\
\text { HCC [68], DLBCL, LC, } \\
\text { Malignant melanoma [69] }\end{array}$ \\
\hline UBE2O & E2-230K & Class IV & $\begin{array}{l}\text { Ubiquitinates BMAL1 to regulate transcriptional } \\
\text { activity and circadian rhythm function [71] } \\
\text { Participating in erythropoiesis, ubiquitinating RPs } \\
\text { to participate terminal erythroid differentiation [75] } \\
\text { Regulating apoptosis } \\
\text { Monoubiquitinating SMAD6 to participate in bone } \\
\text { morphogenesis [76] } \\
\text { Ubiquitinating and degrading MXI1 at the } \\
\text { Lys46 residue }\end{array}$ & $\begin{array}{l}\text { BC [72], GC, RC [5], Anemia, } \\
\text { MM, OC, HNSCC [73], LC [74] }\end{array}$ \\
\hline UBE2Q1 & UBE2Q/NICE5 & Class II & $\begin{array}{c}\text { Regulating p53 [77] } \\
\text { Regulation of lysosome integrity and } \\
\text { lysophagy [80] }\end{array}$ & HCC, BC, ALL [78], CRC [79] \\
\hline UBE2Q2 & Nothing & Class II & Regulating apoptosis & HNSCC [81], CRC [82] \\
\hline UBE2R1 & $\mathrm{CDC} 34 / \mathrm{UBC} 3 / \mathrm{UBCH} 3$ & I3 Class III & $\begin{array}{l}\text { Ubiquitinating and degrading } \mathrm{p} 27^{\mathrm{Kip} 1} \text { [83] } \\
\text { and IKB } \alpha\end{array}$ & $\begin{array}{l}\text { MM, HCC [84], NSCLC [85], } \\
\text { ALL [86] }\end{array}$ \\
\hline UBE2S & E2EPF/EPF5 & Class III & $\begin{array}{l}\text { Ubiquitinating CDKN1A, CCNB1, CDC20, and p53 } \\
\text { (Lys11/Lys48 polyUb chain) to regulate apoptosis } \\
\text { Ubiquitinating } \beta \text {-catenin to maintain its stability } \\
\text { Ubiquitinating SOX2 to regulate neuroectodermal } \\
\text { differentiation and maintaining mES cells [90] }\end{array}$ & $\begin{array}{c}\text { HCC [68], BC, OSCC [87], } \\
\text { NSCLC [88], Melanoma [89], } \\
\text { CRC }\end{array}$ \\
\hline UBE2T & FANCT/PIG50/ & Class III & $\begin{array}{c}\text { Nucleic acid excision repair for UV damage [91] } \\
\text { Ubiquitinating and degrading p53 [101] } \\
\text { Participating in Wnt/ } \beta \text {-catenin signaling and } \\
\text { P13K/AKT signaling, regulating BRCA1 } \\
\text { degradation }\end{array}$ & $\begin{array}{c}\text { FA [65,92], GC [93], } \\
\text { Osteosarcoma [94], PCa [95], } \\
\text { LC [96], BC [97], HCC [98], } \\
\text { Intrahepatic } \\
\text { cholangiocarcinoma [99], } \\
\text { Gallbladder cancer [100], NPC, } \\
\text { CRC, MM [101], OC [102] }\end{array}$ \\
\hline UBE2V1 & UEV1A & Class II & $\begin{array}{l}\text { It participates in the activation of NF- } \mathrm{kB} \text { together } \\
\text { with UBE2N [71] }\end{array}$ & $\begin{array}{l}\text { Metastatic CRC, BC, } \\
\text { Osteosarcoma [103] }\end{array}$ \\
\hline UBE2V2 & MMS2 & Class I & Participates in DNA repair together with UBE2N & - \\
\hline UBE2W & UBC16 & Class I & $\begin{array}{l}\text { UBE2W downregulation promotes cell apoptosis } \\
\text { and correlates with hypospermatogenesis [104] }\end{array}$ & - \\
\hline BIRC6 & Appolon/BRUCE & Class IV & $\begin{array}{c}\text { A positive regulator of } \\
\text { macroautophagy/autophagy [105] }\end{array}$ & $\begin{array}{l}\text { HCC [106,107], NB [35,108], } \\
\text { CRC, PCa [109], OC [35] }\end{array}$ \\
\hline \multicolumn{5}{|c|}{ Ub-like } \\
\hline UBE2F & NCE2 & Class II & Promoting the survival of lung cancer cells [110] & LC \\
\hline UBE2I & UBC9 & Class I & $\begin{array}{l}\text { Promoting the development of T cells [111], } \\
\text { SUMOylation of IRF4 promotes the M2 process of } \\
\text { macrophages [112], SUMOylation of IRF7 limits its } \\
\text { transcriptional activity [113] } \\
\text { SUMOylation of (SUMO1) NLRP3 activates the } \\
\text { inflammasome, Regulating the NF-kB } \\
\text { signaling [115] } \\
\text { Participating in the formation of Lys49 polyUb } \\
\text { chain to resist senescence [116] } \\
\text { Affects BCL2 expression through the ER signaling } \\
\text { pathway [117] } \\
\text { UBE2I-PCGF2 complex inhibits the SUMOylation } \\
\text { of PML-RARA [118] } \\
\text { Participating in the development and survival of } \\
\text { CLPs [119] }\end{array}$ & HCC [114], BC \\
\hline
\end{tabular}


Table 1. Cont.

\begin{tabular}{ccccc}
\hline $\begin{array}{c}\text { Name } \\
\text { (Human) }\end{array}$ & Synonyms & Classification & Biological Roles & Relevant Cancers \\
\hline UBE2M & $\begin{array}{c}\text { UBC12/UBC- } \\
\text { RS2 }\end{array}$ & Class II & $\begin{array}{c}\text { Ubiquitinating a repair [120] } \\
\text { Participating in the cell cycle [125] }\end{array}$ & $\begin{array}{c}\text { HCC [121], RC [122], LC, } \\
\text { Intrahepatic } \\
\text { cholangiocarcinoma [123] }\end{array}$ \\
\hline UBE2Z & USE1/HOYS7 & Class IV & $\begin{array}{c}\text { Participating in the ERK and STAT3 signal } \\
\text { pathway [126] }\end{array}$ & HCC \\
\hline
\end{tabular}

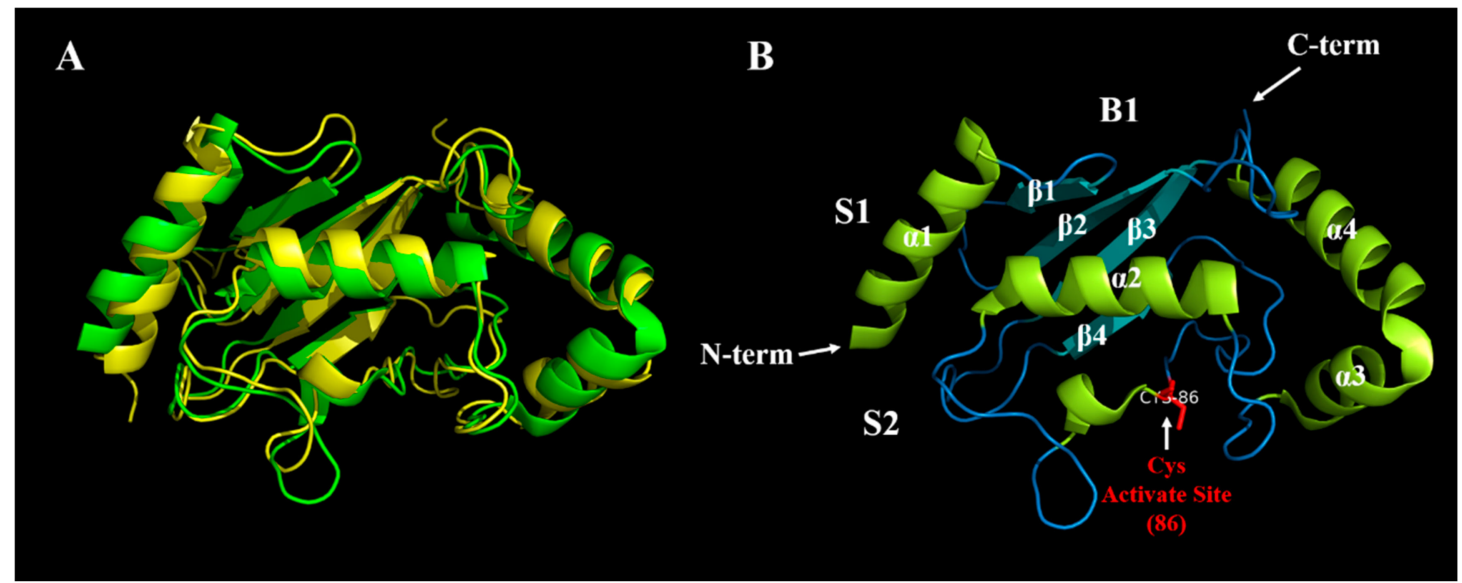

Figure 2. (A) The alignment of UBE2T and UBE2I (Ubl). The three dimensional (3D) structure of UBE2T is shown in green, while UBE2I is shown in yellow, indicating that the structure of E2 family is conserved. UBE2T has a C-terminal extension, which belongs to Class III, while UBE2I has no C- and N- extensions, and so belongs to Class I, which are consistent with the summary shown in Table 1 (B) The 3D structure of UBE2T. We marked four $\alpha$-helixes and four $\beta$ folds with white letters. N-term and C-term refer to the $\mathrm{N}$ - and C-termini of UBE2T, respectively. The main sites of interaction between UBE2T and E1 and E3 are S1 and S2, respectively, and the active site cysteine (86) is highlighted in red. B1 is opposite to the active site of UBE2T, which is called the 'backside.' Backside binding between E2 and $\mathrm{Ub}$ or SUMO contributes to chain building activities or regulates E2 activities via allostery [32]. The 3D structures of UBE2T and UBE2I were downloaded from http:/ / www.rcsb.org/ (accessed on 20 November 2020), numbered 5NGZ and 1A3S, respectively. PyMOL software was used to align them, and the prediction of the active site was carried out using http:/ / www.ebi.ac.uk/interpro/result/InterProScan/iprscan5-R20200618-032207-0413-15289371-p2m/ (accessed on 20 November 2020).

\section{Biological Processes Involving E2s \\ 4.1. DNA Repair Pathway}

Certain proteins are ubiquitinated by radiation or treatment with DNA damaging agents, including proliferating cell nuclear antigen (PCNA), histone H2A and its variant $\mathrm{H} 2 \mathrm{~A}(\mathrm{X})$, 9-1-1 complex, Fanconi (FA) pathway proteins FANCD2 and FANCI, and replication factor 2 [127] (Figure 3). The pathways of E2s involved in DNA damage repair include: DNA translesion synthesis (TLS) and error free pathway targeting PCNA, DNA double strand break repair (DSBR) and the FA pathway centered on $\mathrm{H} 2 \mathrm{~A}(\mathrm{X})$ [33]. In addition, some E2 members are involved in other types of DNA repair processes. The SUMOylation of Xerderma pigmentosum C by UBE2I is to participate in nucleotide excision repair (NER) [128]. UBE2I also plays an important role in DNA-protein crosslinks (DPCs) repair by subsequent proteasome hydrolysis of SUMOylation TOP1/TOP2-DPC (Topoisomerase I/II-DNA-protein crosslink), which repairs the inhibition of DNA metabolism caused by the persistence of TOP (Topoisomerase) [129]. RAD6 mutants are sensitive to alkylating agents, and alkylating agent-induced DNA damage is repaired by base excision repair (BER) pathway, indicating that RAD6 may be involved in BER. UBE2K is involved in these two different repair processes [130]. Damaged DNA can lead to cell cycle arrest and induce the process of DNA repair. Once the damage is repaired, the cells that stop 
the checkpoint will resume the cell cycle. The accumulation of unrepaired DNA usually triggers the activation of multiple cell death or carcinogenic pathways, resulting in cell death, senescence, or cancer [131].

UBE2N cooperates with UBE2V2 to modify PCNA to participate in DNA replication and repair pathways [132]. DNA damage induces monoubiquitination at Lys164 of PCNA, which is catalyzed by UBA1, RAD6, and RAD18 (which also involved in the activation of FA pathway). DNA damage induces nuclear entry of UBE2N and UBE2V2, which are recruited into chromatin by RAD5, where they catalyze PCNA to form a Lys63-linked polyUb chain. RAD6 binds to RAD18 to regulate the TLS pathway of mutant DNA in response to genomic damage, including that induced by chemotherapy and radiotherapy. In the absence of DNA damaging agent, PCNA is modified by SUMO in the S phase, preventing post-replication repair enzymes from being recruited into an inappropriate period of the cell cycle [133] (Figure 3A). UBE2N can also interact with RNF8 and RNF168 to participate in the DNA injury response. OTU domain-containing ubiquitin aldehyde binding protein 1 (OTUB1) regulates DNA repair by hydrolyzing the UBE2N-mediated Lys63 polyUb chain [134].

DSBs can be repaired by homologous recombination (HR) or non-homologous end joining (NHEJ). HR plays an important role in the S/G2 phase of the cell cycle, while NHEJ can function in all phases of the cell cycle [135]. UBE2S was found to be associated with the components of the NHEJ complex and participates in the NHEJ-mediated DNA repair process [136]. The MRN complex (MRE11, RAD50, NBS1) detects DNA DSBs and forms a complex with phosphorylated mediator of DNA damage checkpoint protein 1 (MDC1) and histone H2AX. MDC1 recruits RNF8/UBE2N/UBE2V2, to make H2AX form a Lys63-linked polyUb chain. RAP80 recognizes the Lys63 polyUb chain on H2AX and forms a complex with ABRA1 (Abraxas), BRCC36, breast cancer-1 (BRCA1), and BARD to participate in HR (Figure 3C). OTUB1 inhibits the process via deubiquitination of UBE2N. By collaborating with the heterodimeric E3 ligase RNF20/RNF40, RAD6 catalyzes the monoubiquitination of $\mathrm{H} 2 \mathrm{~B}$ to participate in the regulation of DNA damage repair [137].

UBE2T (also known as FANCT) is first identified in a case of FA, and catalyzes the monoubiquitination of the FANCD2 and FANCI complex with FANCL (RING-type E3). Then, they cluster in DNA interstrand cross-link (ICL) lesions by binding with unknown $\mathrm{X} 1$ or $\mathrm{X} 2$ in the DNA repair process [138] (Figure 3B). The RAD18/RAD6 complex is also crucial to activate the FA pathway. When the repair process is completed, the FANCD2 and FANCI complex is deubiquitylated and dissociated from the repaired ICL site by the USP1-UAF1 complex and is then released from the DNA [139]. The destruction of UBE2T expression leads to FA (a DNA repair defect) by affecting the damage repair response of DNA ICL. On the one hand, it increases the risk of early cancer in adults [140]; on the other hand, it increases the sensitivity of cancer cells to cross-linking agents [141]. Lyakhovich [142] showed that knocking down FANCD2 increased the sensitivity of cancer cells (BC, Bladder, or LC cell lines) to mitomycin C (MMC) and to a lesser extent, to gammarays. Importantly, those cell lines with significant $F A N C D 2$ depletion revealed a decreased recurrence capacity. Ramaeker [143] showed that hypoxia can rapidly and forcefully reduce the level of UBE2T mRNA in cancer cell lines, thus greatly increasing the sensitivity of cancer cells to MMC therapy. Therefore, to reduce the risk of cancer, it is necessary to ensure stable levels of UBE2T and other proteins involved in the FA pathway. To treat patients with cancer, the combination of DNA cross-linking agents (e.g., MMC, Cisplatin (DDP)) with inhibitors of the FA pathway might kill cancer cells by preventing them from replicating and repairing. UBE2T can also promote the removal of DSBs in the process of DNA HR repair [144].

Overall, in normal cells, E2s are involved in DNA repair and restart of damaged DNA replication forks to maintain genomic integrity and reduce the incidence of cancer [145]. The increased expression and activation of DNA damage response signals and repair genes are the reasons for the resistance of cancer cells to radiotherapy [146]. Downregulation of UBE2S expression in Glioblastoma (GBM) suppressed NHEJ-mediated DSBR, and made 
GBM cells more sensitive to radiotherapy [136]. RAD6 regulates mutagenic TLS and FA in response to various genomic insults, including chemo and radiation therapy [147]. TZ9 (a RAD6-specific small molecule inhibitor) treatment of triple negative breast cancer (TNBC) and OC cells weakens the DNA repair signal of these cells, thus increasing the sensitivity of drug-resistant cancer cells to carplatin [148]. UBE2B regulates the sensitivity of nasopharyngeal carcinoma (NPC) cells to carmustine (BCNU) by ubiquitination of MGMT (a DNA repair enzyme) [149]. UBE2D3 had the opposite effect, and its downregulation promoted DNA damage repair in esophageal cancer cells and enhanced the radiation resistance of cancer cells [150]. We know that NHEJ-mediated DSBR exists in all stages of the cell cycle, and the repair process is fast but inaccurate. Although HR-mediated DSBR only exists in the S/G2 phase of the cell cycle, the repair process is complex but accurate. Therefore, UBE2S and UBE2N, which are involved in these two processes, can be considered as anticancer targets. In view of the ineffectiveness of radiotherapy and emergence of chemotherapy resistance, it is urgent to develop inhibitors of DNA damage repair signals. Combining the inhibitors with radiotherapy and chemotherapeutic drugs mighty increase the effectiveness of cancer treatment. This requires further study.

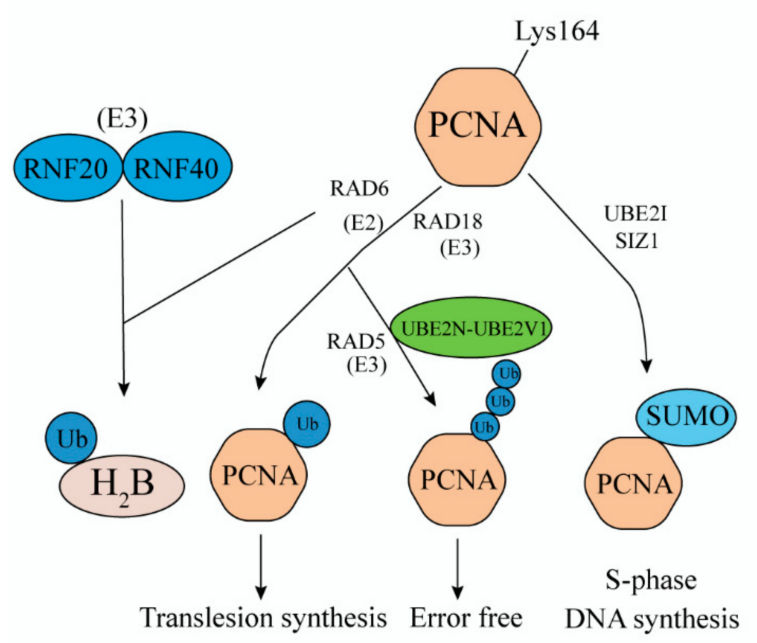

A

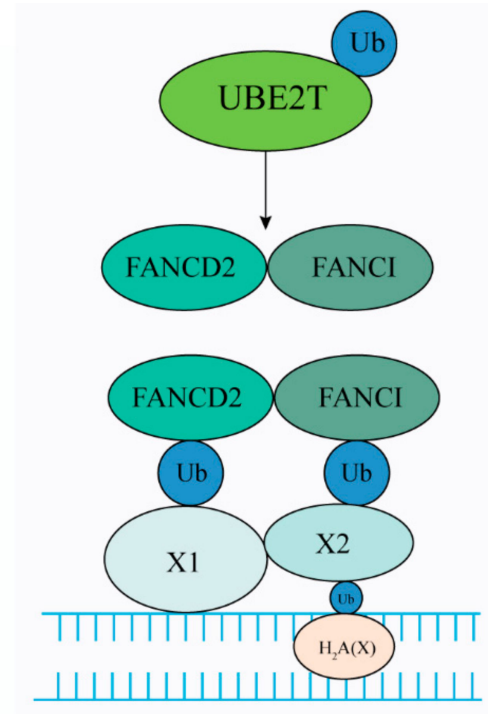

B

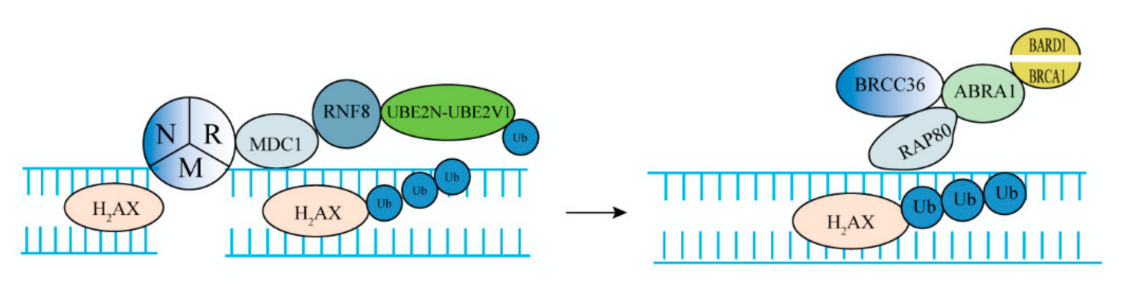

C

Figure 3. E2s participate in the DNA repair pathway. (A) E2 ubiquitinates proliferating cell nuclear antigen (PCNA) to participate in the DNA replication and repair process. (B) E2 ubiquitinates the FANCD2 and FANCI complex to participate in the FA pathway. (C) E2 ubiquitinates $\mathrm{H} 2 \mathrm{~A}(\mathrm{X})$ to participate in the DNA replication and repair process. UBE2D3 can also participate in the above $(\mathbf{A}, \mathbf{C})$ processes [151].

\subsection{Cell Cycle}

Cell cycle progression is monitored by a set of checkpoints G1/S, G2/M, and spindleassembly checkpoint (SAC) that push cells forward from one stage to the next [35], and their transformation depend largely on the UPP (Figure 4A). Kinase inhibition protein p27 (p27 $\left.{ }^{\text {Kip1 }}\right)$, as an inhibitor of cyclin-dependent kinase (CDK), can be ubiquitinated by UBE2D and UBE2R1 in the transition of G1max to S phase, thus alleviating the in- 
hibition of the CDK4/CDK6 complex [152]. The genes regulated by p27 ${ }^{\text {Kip1 }}$ are closely associated with poor cancer survival, indicating that $\mathrm{p} 27^{\mathrm{Kip} 1}$ is associated with cancer progression [153]. UBE2D3 is also the initial ubiquitination enzyme for key regulatory molecules such as cell cyclin D1 (CCND1), inhibitor of nuclear factor kappa B (IKB), p53, and MDM2 [154]. UBE2R1 and UBE2R2 participate in the extension of cell cyclin E (CCNE) ubiquitin chain [155]. UBE2C has been proposed to be rate-limiting in the late G1 phase, when it is required to degrade cell cyclin A by APC/C to prevent premature DNA replication [156]. RAD6 influences the transcription of CDK1 by increasing monoubiquitinylation of $\mathrm{H} 2 \mathrm{~B}$ and trimethylation of $\mathrm{H} 3 \mathrm{~K} 4$ in the $C D K 1$ promoter region. Therefore, RAD6 promotes G1/S phase transition and cell proliferation [157]. In addition, SUMO also plays a significant role in the cell cycle, and CDK1, CDK9, CDK11, and CCNE have been identified as targets of SUMO [158]. In GBM cells, SUMOylation of CDK6 can prevent its ubiquitination and degradation, and ensure its existence in the process of G1/S transformation [159]. In the transition of $\mathrm{G} / \mathrm{M}$ phase, this process is promoted by ubiquitination of WEE1 [160].

$\mathbf{A}$

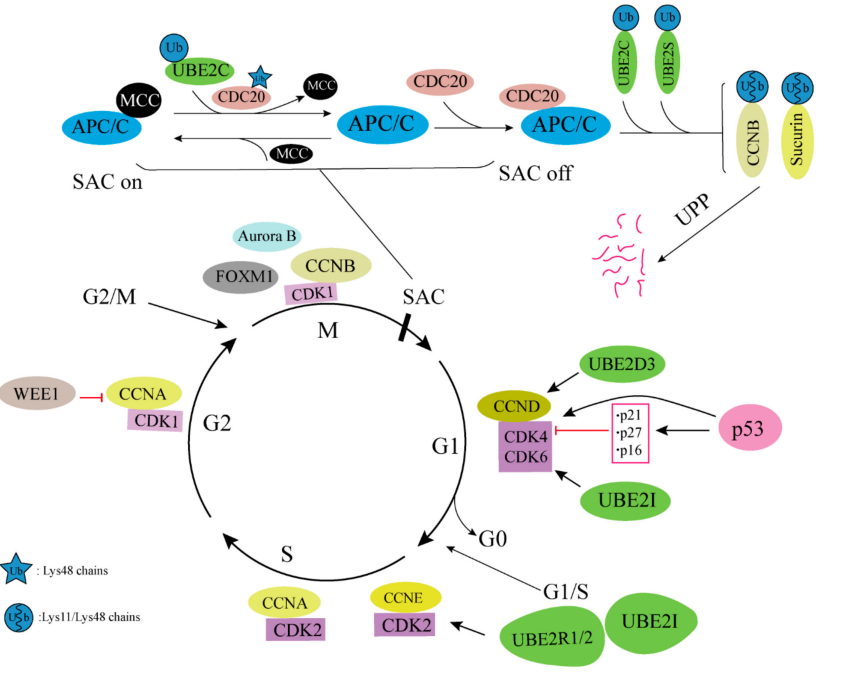

B

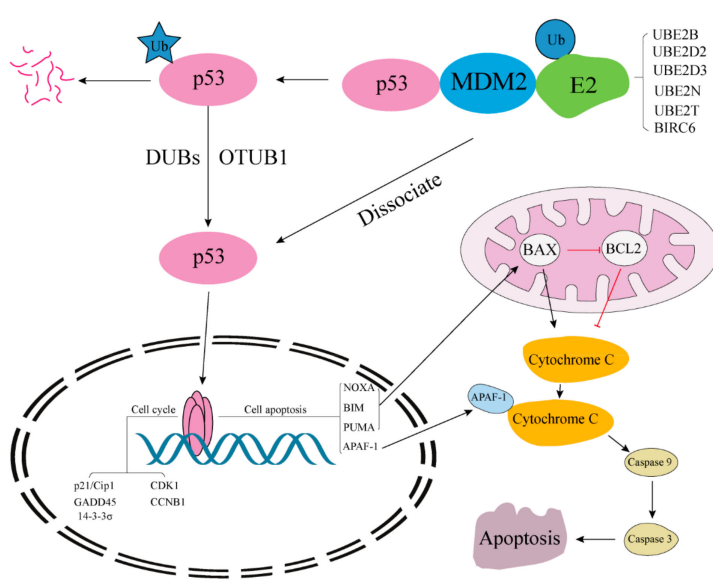

Figure 4. (A) E2s participate in the cell cycle process. (B) E2s regulate the cell cycle and apoptosis process by ubiquitinating p53. p53 upregulated modulator of apoptosis (PUMA) and BCL2-associated X (BAX) can induce apoptosis through increasing mitochondrial outer membrane permeability.

SAC ensures an equal distribution of chromosomes to daughter cells during mitosis [161]. Improper SAC results in malignancies or birth defects. APC/C (SAC inhibits $\mathrm{APC} / \mathrm{C}$ ) is also one of the determinants of precise division of genetic material during mitosis [162]. The inhibition of APC/C by SAC is inhibited by the tetramer binding of mitotic checkpoint complex (MCC) formed by cell division cycle 20 (CDC20), MAD2, BUBR1, and BUB3 in the G2/S phase (Figure 4A). UBE2C has been reported to be required to dissociate the MAD2-CDC20 complex by ubiquitylating CDC20, thus releasing the MCC [163]. Inactive $\mathrm{APC} / \mathrm{C}$ is activated by binding with free CDC20, and then the activated APC/C ubiquitinates securin and cell cyclin B1 (CCNB1) via UBE2C and UBE2S [164]. Subsequently, securin and CCNB1 are ubiquitinated and degraded rapidly, resulting in the transition from metaphase to anaphase of mitosis [165]. The recognition of different ubiquitin chains by proteasomes gives different "priority" to the degradation of substrates. The heteromorphic Lys11/Lys48 chains mediated by UBE2C and UBE2S in the cell cycle are vital for the orderly and accurate progress of the cell cycle [166]. The formation of heterotypic chains with multiple different lysine linkages on CCNB1 is determined by the concentration of UBE2C within the $\mathrm{APC} / \mathrm{C} \mathrm{Ub}$ reaction. Low concentrations of UBE2C form heterotypic chains predominantly containing Lys11/Lys48 linkages, but at high concentrations, UBE2C forms complex chains with six different Ub linkages. UBE2C or UBE2D co-operate with APC/C for the initial ubiquitin attachment to substrates, while UBE2S co-operates with APC/C for subsequent ubiquitin attachments, producing Lys11 chains [167]. 
In addition, UBE2C, UBE2D2, UBE2D3 [168], UBE2N, UBE2Q1, UBE2S, and UBE2T [169] can affect the stability and activity of p53 protein to mediate cell cycle arrest. p53 acts as a homotetramer transcription factor, regulating the expression of genes including transactivation of its target genes, including cyclin dependent kinase inhibitor $1 A$ (CDKN1A, also

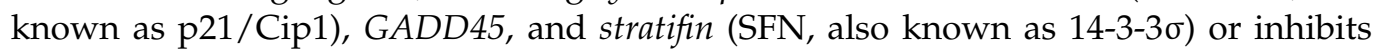
CDC2 and CCNB1 expression [170]. Mutation of p53 upregulates CCND1 and downregulates $C D K N 1 A$, leading to a highly active CDK4/CDK6 complex and thus ensuring uninterrupted pancreatic cancer cell division and uncontrolled cell proliferation [171]. Overexpression of UBE2S in HCC functions as an oncogene by increasing the ubiquitination of p53 [172]. HEK293 cells overcame radiation-induced G2/M cell cycle arrest through ubiquitination of p53 via UBE2K. Phosphorylated UBE2K inhibits p53, thereby suppressing the expression of CDKN1A, and sequentially stimulating CCND and CCNE to induce re-entry into the cell cycle. This suggests that UBE2K plays a regulatory role in ultraviolet-induced cell cycle arrest and re-entry $[173,174]$. Knockdown of UBE2Q1 reduced HCC cell proliferation, promoted apoptosis via induction of GADD $45 \alpha$, and suppressed orthotopic tumorigenicity both in vitro and in vivo [175].

Disorders of cell cycle progression play a key role in the formation and development of cancer, and the abnormal regulation of the cell cycle often leads to the occurrence and development of cancer. UBE2S is highly expressed in melanoma cells and tissues. Treatment of melanoma cells with a short hairpin RNA targeting UBE2S led to cell cycle arrest in the G1/S phase and inhibition of cancer cell growth [176]. UBE2T knockout can significantly inhibit the proliferation and colony formation of bladder cancer cells, induce cell cycle arrest, and increase the rate of apoptosis, which might be related to the fact that $U B E 2 T$ is the target gene promoted by the E2F transcription factor [177]. Inhibition of $U B E 2 T$ in GC cells arrested the cell cycle in the G2/M phase, and ultimately inhibited cell proliferation and colony formation [178]. UBE2C and APC/C affect the proliferation rate and cell cycle distribution of esophageal cancer cells by interfering with the level of CCNB [179]. The cell cycle regulator FOXM1 binds to the UBE2C promoter region in esophageal cancer cells and activates its transcription, leading to upregulation of UBE2C expression [180]. Overexpression of UBE2C can also induce epithelial to mesenchyme transition (EMT) related to cancer cell invasion and metastasis through the APC/C complex and Wnt/ $\beta$-catenin [7], P13K/AKT, and p53 [181] signaling pathways. EMT is closely related to the occurrence and development of cancer. Silencing UBE2C causes pancreatic ductal adenocarcinoma cells to block in the G1/S phase, and reduces the levels of EMT markers (VIM, E-cadherin) [182]. E2s that regulate EMT also include UBE2O, UBE2V1, and UBE2T [183]. Flavopiridol can significantly inhibit the activity of CDKs $(1 / 2 / 4 / 6 / 7)$ by interacting with the ATP binding pocket on the kinase, thereby causing G1/G2/M phase block. It is a classic non-selective CDK inhibitor and has successfully entered clinical trials [184]. Thus, blocking the cell cycle of malignant cell proliferation-associated diseases, such as cancer, will be the basis for developing new drugs for many years. However, it can be seen from the above that UBE2C and several special E2s promote the progress of cell cycle. At the same time, UBE2N and other E2s regulate p53 to regulate cell cycle. Therefore, the regulation of E2s on cell cycle is complex and extensive, which requires further study of the unique role of single $\mathrm{E} 2$ in cancer cell.

\subsection{Apoptosis}

The UPP plays a key role in the regulation of apoptosis. Currently, three apoptosis pathways are studied, namely the death receptor-mediated pathway, the mitochondriamediated pathway, and the endoplasmic reticulum pathway [185]. Regulatory factors of apoptosis include B-cell leukemia/lymphoma 2 protein family (BCL2), inhibitor of apoptosis proteins (IAPs), and IKB kinase (IKK) regulatory factors. Some regulatory molecules involved in apoptosis have been identified as proteasome substrates [186]. BIRC6 is a member of the IAP family. Its overexpression prevented apoptosis by ubiquitinating and degrading second mitochondria-derived activator of caspases (SMAC) and caspase 9 in 
mouse fibroblasts [187]. BIRC6 can also bind to other active caspases, including caspases 3, 6 , and 7, and such interactions have been shown to underlie its ability to inhibit the caspase cascade and ultimately apoptosis [188]. Knockout of BIRC6 can block the CRC cell cycle in the S phase and increase apoptosis [189]. High levels of BIRC6 protein are related to poor clinical manifestations of patients with prostate cancer (PCa) [190], non-small cell lung cancer (NSCLC) [191], acute leukemia [192], and epithelial OC [35], which are related to poor prognosis. It can be seen that targeting E2 member BIRC6 in cancer cell can release the inhibition and degradation of caspase activity, thus affecting the survival of cancer cell. Inhibition of apoptosis prevents the death of cancer cells, either associated with carcinogenic initiation or cancer therapy [193]. UBE2O-mediated c-Maf ubiquitination and degradation, which can induce multiple myeloma cell apoptosis [194]. UBE2M promoted osteoarthritis chondrocyte apoptosis by activating the Axin-dependent Wnt/ $\beta$-catenin pathway [195].

Certain E2s, such as UBE2B, UBE2C, UBE2D, UBE2Q, and BIRC6, function to regulate cell apoptosis through the ubiquitination and degradation of p53. p53 regulates apoptosis by regulating genes such as PUMA, NOXA, BIM, BAX, BCL2, FAS, and IGFBP3 (Figure 4B), and it can also induce cell apoptosis through the death signal receptor protein pathway (TNF receptor and Fas protein) [182]. Suppression of UBE2D can stabilize p53, leading to enhanced apoptosis and markedly inhibited proliferation of human LC cells in a p53dependent manner [196]. The mutation of BIRC6 led to upregulation of p53, resulting in mitochondrial apoptosis [197]. The upregulation of UBE2D1 in HCC promoted the growth of HCC, which was achieved by mediating the ubiquitination and degradation of p53 [198]. Complete silencing of UBE2I in RAW264.7 cells resulted in apoptosis. Downregulation of UBE2I decreased the level of the BCL2 protein in HepG2 cells and thus caused HCC cell apoptosis [117]. These reports showed that UBE2I is necessary for cancer cell survival. The above studies indicated that multiple E2 members can directly or indirectly regulate the apoptosis of cancer cells. To a large extent, the drug resistance of cancer cells is also based on the resistance to apoptosis. This observation will be useful to develop treatments for diseases such as cancer and abnormal cell proliferation.

\subsection{The Wnt/ $\beta$-Catenin Pathway}

Wnt/ $\beta$-catenin signaling pathway plays an important role in embryonic development [199]. As the core component of this pathway, $\beta$-catenin is tightly regulated by posttranslational modifications that fine-tune its protein level and optimal activity. $\beta$-catenin is phosphorylated by CK1 and GSK-3 $\beta$ and then enters the UPP. Under the combined action of SKP1/CUL1/F-box protein complex- $\beta$-transducin repeat-containing protein $(\mathrm{SCF}-\beta \operatorname{TrCP})$ and some E2s, $\beta$-catenin is degraded, which stabilize the concentration of $\beta$-catenin in the cytoplasm and block the Wnt/ $\beta$-catenin signaling pathway [200]. As a novel activator of the $\mathrm{Wnt} / \beta$-catenin signaling pathway, UBE2S modifies $\beta$-catenin at Lys19 via a Lys11-linked polyUb chain. This modification promotes $\beta$-catenin stabilization through antagonizing its Lys48-linked proteasomal degradation, mediated by the destruction complex / $\beta$ TrCP signaling [201]. UBE2B can also stabilize $\beta$-catenin through the Lys63-linked polyUb chain, and silencing $U B E 2 B$ can inhibit the transcription activity of $\beta$-catenin [202]. This is because $U B E 2 B$ is the transcription target of $\beta$-catenin/T-cell factor. Even if $\beta$-catenin is ubiquitinated, it is stable and transcriptionally active, indicating that there is positive feedback regulation between UBE2B and $\beta$-catenin [203].

If the activity of E2 or E3 changes, it will destroy the stability of $\beta$-catenin. The concentration of $\beta$-catenin might increase in the cytoplasm, which in turn activates the $\mathrm{Wnt} / \beta$-catenin signaling pathway, and ultimately regulates the transcription of target genes C-MYC, CCND1, and matrix metalloproteinase 7 (MMP7) [204]. Overexpression of UBE2S significantly upregulated the expression of $\beta$-catenin, CCND1, and MMP7, and the activity of Wnt/ $\beta$-catenin signaling in A549 cells [205]. In addition, since Wnt/ $\beta$-catenin signaling is crucial for the activity of epithelial stem cells, it is not surprising that $\mathrm{Wnt} / \beta$-catenin pathway mutations are frequently observed in carcinomas [206]. The positive regulatory relationship between UBE2S and hypoxia-inducible factor $1 \alpha(\mathrm{HIF}-1 \alpha)$ in cancer cells might 
contribute to greater proliferation, angiogenesis, and metastasis of cancer [207]. Overexpression of UBE2S can also activate $\beta$-catenin signaling by downregulating SOX6, inhibiting the activity of CCNB1, and promoting the proliferation and migration of endometrial cancer cells [208]. UBE2T downregulation suppressed the activity of the Wnt/ $\beta$-catenin signaling pathway, which ultimately suppressed NSCLC cell proliferation, migration, and invasion in vitro [209]. The pathway activation and in vitro pro-metastasis effects of UBE2T were blocked using an AKT inhibitor. Therefore, UBE2T might promote the development and progression of NPC by activating the AKT/GSK3 $\beta$ / $\beta$-catenin pathway [210]. However, it remains challenging to develop effective molecules that specifically target this pathway to improve cancer therapy. We believe that maintaining the activity and expression level of related E2s in cancer cells might be a way to control cancer cell proliferation and metastasis.

\subsection{Nuclear Factor-Kappa B (NF-кB) Pathway}

E2s participate in signaling pathways by modifying certain key substrates, including mTORC1, PTEN-AKT, TNF, TLR, NLR, RLR, and TCR. In addition to acting through $\mathrm{NF}-\mathrm{kB}$, it also acts through interferon regulatory factors (This topic has recently been expertly reviewed [211]). The NF- $\kappa B$ signaling system (including the NF- $\kappa B$ dimer, I $\kappa B$, and IKK) can respond to stimuli from a variety of signaling pathways such as TNF, TLR, NLR, RLR, and TCR [212]. Although NF-KB exists widely, it exists in an inactive state in most cells. This is because NF- $\mathrm{KB}$ is "trapped" by I $\mathrm{KB}$ in the cytoplasm of unstimulated cells [213]. The degradation of I $\mathrm{KB}$, the key inhibitor of NF- $\kappa \mathrm{B}$, is coordinated by at least four post-translational modifications, allowing activation only when several prerequisites are met [165]. Under the action of various stimulating factors, including microorganisms, UBE2N and UBE2V1 form a heterodimer, which binds to the loop domain of TNF receptor associated factor (TRAF) family of adaptor proteins. This promotes the activation of TNFR and TLR protein kinases involved in signal transmission [214]. UBE2D1 can collaborate with c-IAP1 and mediate TNF- $\alpha$ stimulated receptor-interacting protein 1 (RIP1) ubiquitination [215]. UBE2N-UBE2V1, TRAF6, and TRAF2 are involved in the formation of Lys63-linked chain on NF-KB essential modifier (NEMO)/IKK $\gamma$ and/or RIP1 [216-219]. After a series of reactions, I $\mathrm{KB}$ is phosphorylated and activated. After phosphorylated I $\mathrm{kB}$ enters the UPP, it forms a Lys48-linked ubiquitin chain under a two-step mechanism mediated by UBE2D and UBE2R1 [220]. Finally, IкB is rapidly degraded, releasing NF- $\kappa B$ into the nucleus, where it activates the transcription of a series of genes [221] (Figure 5). UBE2N-UBE2V1 not only mediates NF- $\mathrm{kB}$ activation, but also activates the RHBDF2-TACE signaling pathway to antagonize NF- $\mathrm{kB}$ activation. Thus, UBE2N-UBE2V1 plays dual roles in regulating the NF-KB pathway [222]. Besides, UBE2I also has a dual role in the regulation of NF-kB. SUMO1 acylates IKB and inhibits its ubiquitination, while SUMO2/3 plays the opposite role, that is, it promotes the ubiquitination and degradation of IKB [223]. The products of NF- $\mathrm{KB}$ target genes TNFAIP (TNF alpha induced protein 3, also known as A20) and $I \kappa B \alpha$ terminate NF- $\kappa B$ activation.

In normal cells, NF- $\mathrm{kB}$ becomes activated only after the appropriate stimuli, and then upregulates the transcription of its target genes [224]. In cancer cells, different types of molecular alterations might result in impaired regulation of NF- $\mathrm{kB}$ activation. In such case, NF- $\mathrm{kB}$ loses its inducibility and becomes constitutively activated [225]. This leads to deregulated expression of genes under NF- $\mathrm{kB}$ control. Although NF- $\mathrm{KB}$ is known to regulate immune and inflammatory responses, it also regulates the expression of cancer cell related genes such as those involved in proliferation (e.g., CCND1), angiogenesis (e.g., $V E G F$ ), invasion (e.g., MMP9), metastasis (e.g., ICAM1), and apoptosis (Promoting apoptosis (e.g., FAS) or Inhibiting apoptosis (e.g., BCL2)) [226]. UBE2V1 mRNA levels appeared to be elevated in all cancer cell lines examined [227]. Constitutive high-level expression of UBE2V1 alone in cultured human cells was sufficient to cause a significant increase in NF- $\mathrm{kB}$ activity, as well as the expression of its target anti-apoptotic protein, BCL2 [228]. Overexpression of UBE2V1 can inhibit stress-induced apoptosis of HepG2 cells by activating $\mathrm{NF}-\mathrm{kB}$ signaling. Overexpression of UBE2V1 alone in BC cells was sufficient to activate 
NF- $\mathrm{kB}$, which in turn upregulated the MMP1 expression to enhance BC cell metastasis [229]. Collectively, these observations establish a close correlation between UBE2V1 expression and tumorigenic potential. The $\mathrm{N}$-terminal region of UBE2V1 is the molecular determinant of its cellular functions in the NF- $\mathrm{kB}$ signaling pathway. Therefore, an ideal inhibitor should target the N-terminal region of UBE2V1 instead of the UBE2N-UBE2V1 interface. RIP1 forms a Lys11-linked polyUb chain under the action of UBE2D, UBE2S, and c-IAP1. NEMO effectively binds to the Lys11-linked polyUb chain, which might play a signal role in the activation of cell proliferation pathways [230]. After NF-KB is activated, it can stimulate activated macrophages to release pro-inflammatory mediators and promote the growth of cancer cells [231]. These imply a tumor promotion function of E2.

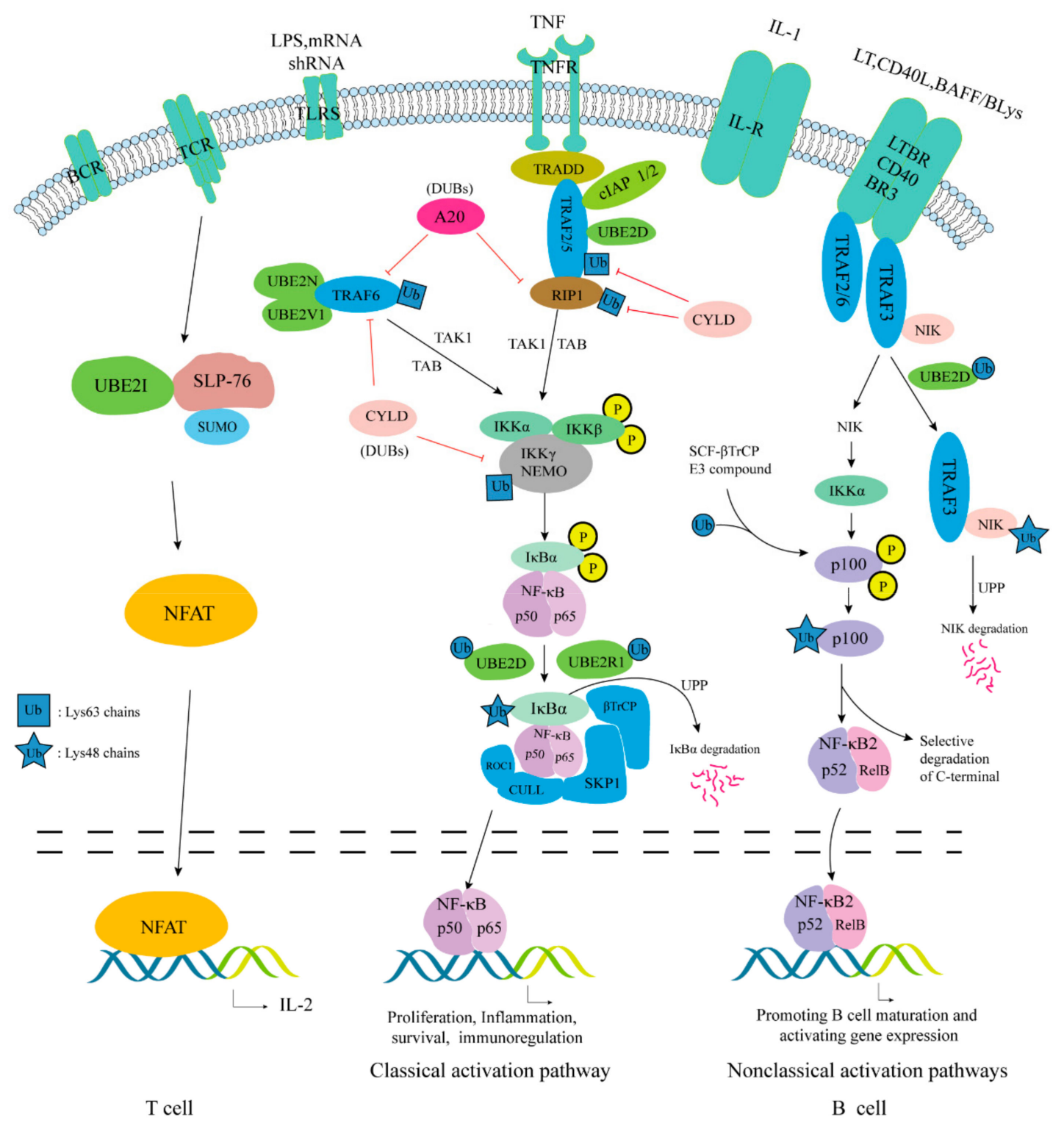

A

B

C

Figure 5. E2s participate in the NF-KB pathway. (A) T cell receptor (TCR) stimulation promotes the binding of SLP-76 and UBE2I and increases the SUMOylation of SLP-76. SLP-76 and UBE2I synergize to augment TCR-mediated IL2 transcription by nuclear factor of activated T cells (NFAT) in a manner dependent on SUMOylation of SLP-76 [232]. (B) Under the action of the stimulation signal, IKB $\alpha$ will rapidly undergo phosphorylation modification under the stimulation of IKK. IKK contains two catalytic subunits, IKK $\alpha$ and IKK $\beta$, and one regulatory subunit IKK $\gamma$ [225]. In the classical pathway, IKK $\beta$ phosphorylates IKB $\alpha$ and is then recruited into the SKP1/CUL1/F-box protein (SCF) complex via $\beta \operatorname{TrCP}$ containing the F-box domain. $\beta \operatorname{TrCP}$ contains a WD40-repeat domain, which can specifically bind to two phosphorylated serine sites on 
the $\mathrm{N}$-terminus of IKB $\alpha$ [233]. The RING domain contained in ROC1 can recruit E2 and to polyubiquitinylate phosphorylated $\mathrm{I} \kappa \mathrm{B} \alpha$, so that it is degraded by the $26 \mathrm{~S}$ proteasome and "releases" NF- $\kappa \mathrm{B}$ into the nucleus [234]. (C) In the non-classical pathway, activation of the pathway was suggested to depend on receptor-induced TRAF3 degradation and stabilization of NF-kB inducing kinase (NIK) [235]. TRAF3 physically associates with NIK via a specific sequence motif located in the N-region of NIK and ubiquitinates NIK to stabilize it with UBE2D [226]. CD40 and B cell activativing factor belonging to the TNF family (BAFF) of the tumor necrosis factor (TNFR) superfamily activate NIK selectively, and then NIK phosphorylates and activates IKK $\alpha$. Activated IKK $\alpha$ catalyzes the phosphorylation of the two Ser sites at the C-terminus of the p100 precursor protein, and the phosphorylated modified p100 is recognized by the SCF- $\beta$ TrCP complex [236]. The proteasome only degrades the C-terminus of p100 that contains ankyrin repeats, but does not affect the N-terminus (that is, the p52 subunit) containing the rel-homology domain (RHD) [237]. Then, p52 combines with RelB to form a dimer, which promotes the expression of target genes that can mature and activate B cells [238].

\subsection{Other Cases}

The number of identified substrates conjugated by a particular Ub varies considerably, with tens of thousands of substrates identified for ubiquitin, thousands for SUMO, just a few for URM1, and two for ATG [32]. Therefore, there are many more E2s modified substrates that could participate in the regulation of cancer. For example, the UBE2NUE2V1A complex and TRAF6 together trigger the Lys63 ubiquitination of AKT kinase. Then, AKT is phosphorylated to inhibit the regulation of BC cell cycle arrest and apoptosis by the FOXO1 transcription factor [239]. UBE2N activates non-SMAD signals through the TAK1-p38 MAP kinase cascade to regulate BC transfer, which is achieved by UBE2N activation of mitogen-activated protein/ERK kinase kinase 1 (MEKK1) and TAK1 [11]. UBE2T promoted the proliferation of renal cell carcinoma cells by regulating P13K/AKT signaling, suggesting that it might be a novel target for the treatment of patients with renal cell carcinoma [240]. UBE2N and UBE2D are required to initiate monoubiquitination and subsequent polyubiquitination of MHC class I molecules, which is necessary for their efficient endocytosis and endolysosomal degradation [241]. The UBE2D complex is critical to maintain KRAS protein stability, and targeting such a complex might be a unique strategy to degrade mutant KRAS to kill cancer cells [242]. Downregulation of UBE2O promoted AMPK $\alpha 2$-mediated suppression of the (mTORC1)-HIF-1 $\alpha$ pathway, which is essential for metabolic "reprogramming" of cancer cells [243]. SUMOylated collapsin response mediator protein 2 (CRMP2) exists widely in GBM cells. Inhibition of CRMP2 SUMOylation could suppress GBM proliferation significantly in vitro [244].

Although cancers are derived from numerous tissues with multiple etiologies, and its progression carries with bewildering and seemingly endless combination of genetic and epigenetic alterations. However, there is a relatively small amount of "mission critical" events: deregulated cell proliferation and suppressed apoptosis. E2s not only promote the overexpression of these "mission critical" events in cancer cells, but also promote the progress of their entire life cycle. Understanding the biological processes involved and the related cancers are necessary for the initial selection of anti-cancer targets (Table 1).

\section{Inhibitors and miRNAs Targeting E2s}

Cancer cells' rapid division and disordered regulatory pathways make them more susceptible to proteasome inhibition; therefore, proteasome inhibitors have become a new class of chemotherapeutic drugs that cause cell cycle arrest and cell death. We know that the UPP is currently one of the most widely studied target in disease treatment. Velcade and Krypolis, which inhibit the activity of the $26 \mathrm{~S}$ proteasome, have been developed successfully to treat a variety of blood diseases [245]. The proteasome is the last step of the ubiquitination process and targets large amounts of ubiquitinated proteins for degradation; therefore, inhibiting the proteasome might lead to the accumulation of upstream ubiquitinated proteins. This could have serious consequences, which limit the widespread use of these drugs. Therefore, we could turn our attention to the specific components in the UPP, which might be a better strategy to specifically suppress them. Currently, inhibitors targeting E3 
ligases and DUBs have been used in clinical trials to treat cancer [246]. Inhibitors targeting E2s are still in basic research, such as preliminary screening. There are few E1s; therefore, targeting E1s might affect multiple ubiquitination pathways. Based on the central position of E2s in the UPP and their appropriate quantity and special structure, one or more of E2s could be considered as targets to develop anticancer drugs, so as to provide the specificity that E1 inhibitors cannot achieve.

Most of the E2 inhibitors currently studied change activity of E2s by binding to the active site, allosteric site, or protein interaction site (Table 2). UBE2I is an anti-cancer target for cancers driven by MYC and RAS/RAF. Researchers used the X-ray crystal fragment screening method to find an allosteric small molecule binding site on the back of UBE2I. They believe that compounds that bind to this site might interfere with various proteinprotein interactions in UBE2I's activities [247]. It was reported that arsenic can cross-link adjacent cysteines in the catalytic domain of UBE2O, which can be used as a method to inhibit UBE2O activity. Arsenic is currently in clinical trials for various cancers [30]. The ligand molecules of the UBE2D2 activate site obtained through virtual screening include pyridine, piperidine, and azol ring scaffolds, which can be used as candidates for the development of anticancer drugs [248].

Table 2. Inhibitors and miRNAs targeting E2s.

\begin{tabular}{|c|c|c|c|c|c|}
\hline Name & Target & Origin & Inhibition Mechanisms & Test Diseases & Characteristics \\
\hline \multicolumn{6}{|c|}{ Inhibitors } \\
\hline IJ-5 [249] & UBE2D3 & Herb & $\begin{array}{l}\text { Combines with Cys85 of UBE2D3 to } \\
\text { inhibit NF-kB signaling }\end{array}$ & $\begin{array}{l}\text { Arthritis, } \\
\text { Hepatitis }\end{array}$ & Difficulty in synthesis \\
\hline $\begin{array}{l}\text { Compound 6d } \\
\text { [250] }\end{array}$ & UBE2D3 & $\begin{array}{l}\alpha \text {-Santonin } \\
\text { derivatives }\end{array}$ & Same as above & Arthritis & $\begin{array}{c}\text { The efficacy of } 6 \mathrm{~d} \text { is } \\
\text { greater than IJ-5, but } 6 \mathrm{~d} \\
\text { is unstable }\end{array}$ \\
\hline $\begin{array}{c}\text { 1ß-hydroxy } \\
\text { alantolactone }[251]\end{array}$ & UBE2D & Herbal medicine & Same as above & Inflammation & $\begin{array}{l}\text { It is more efficient in } \\
\text { combination with } \\
\text { UBE2D3 }\end{array}$ \\
\hline CW3 [252] & UBE2G2 & Synthesis & $\begin{array}{l}\text { The vinyl group of CW3 inhibits E2 by } \\
\text { forming a covalent bond with the thiol } \\
\text { group of Cys48 of UBE2G2 }\end{array}$ & Melanoma & - \\
\hline TZ9 [253] & UBE2B & Synthesis & - & $\mathrm{BC}$ & Selective suppression \\
\hline $\begin{array}{l}\text { New triazine drugs } \\
\quad(6 a-c)[151]\end{array}$ & UBE2B & $\begin{array}{l}\text { Based on TZ9 } \\
\text { synthesis }\end{array}$ & $\begin{array}{l}\text { It incorporates deep inside the UBE2B } \\
\text { binding pocket by interaction with } \\
\text { UBE2B active site residues Cys } 88 \\
\text { and Asp90. }\end{array}$ & $\begin{array}{l}\mathrm{OC}, \mathrm{LC}, \mathrm{BC} \\
\mathrm{CC}\end{array}$ & $\begin{array}{l}\text { Inhibitory activity }> \\
\text { TZ9, Selective } \\
\text { suppression }\end{array}$ \\
\hline CC0651 [254] & UBE2R1 & Synthesis & $\begin{array}{l}\text { It inserts into the hidden binding pocket } \\
\text { of the non-catalytic site of UBE2R } 1 \text { and } \\
\text { interferes with the release of Ub to the } \\
\text { Lys residue of the substrate }\end{array}$ & - & Allosteric inhibition \\
\hline 2-D08 [255] & UBE2I & Synthesis & $\begin{array}{l}\text { Preventing transfer of SUMO from the } \\
\text { UBE2I-SUMO thioester to the substrate }\end{array}$ & - & $\begin{array}{l}\text { In vitro biochemical } \\
\text { test }\end{array}$ \\
\hline Compound 2 [256] & UBE2I & Synthesis & Binding near the active site of UBE2I & - & $\begin{array}{l}\text { Low potency, low } \\
\text { selectivity }\end{array}$ \\
\hline $\begin{array}{l}\text { Leucettamol A } \\
\text { [257] }\end{array}$ & UBE2N & $\begin{array}{l}\text { Leucetta aff. } \\
\text { microrhaphis }\end{array}$ & $\begin{array}{l}\text { Inhibiting the formation of the } \\
\text { UBE2N-UBE2V1 complex }\end{array}$ & - & $\begin{array}{c}\text { Its hydrogenation } \\
\text { increased its inhibitory } \\
\text { activity }\end{array}$ \\
\hline $\begin{array}{l}\text { Manadosterols A } \\
\text { and B [258] }\end{array}$ & UBE2N & $\begin{array}{l}\text { Lissodendoryx } \\
\quad \text { fibrosa } \\
\text { manadosterols }\end{array}$ & Same as above & - & $\begin{array}{l}\text { The activities are more } \\
\text { potent than those of } \\
\text { Leucettamol A }\end{array}$ \\
\hline NSC697923 [259] & UBE2N & Synthesis & $\begin{array}{l}\text { Impeding the formation of the UBE2N } \\
\text { and } \mathrm{Ub} \text { thioester conjugate. }\end{array}$ & NB & $\begin{array}{l}\text { Efficacy }>\text { Doxorubicin } \\
\text { and Etoposide }\end{array}$ \\
\hline $\begin{array}{l}\text { Luteolin and } \\
\text { Quercetin [260] }\end{array}$ & UBE2S & Plants & - & Cervical cancer & - \\
\hline CU2 [261] & UBE2T & Synthesis & $\begin{array}{l}\text { Inhibiting UBE2T/FANCL-mediated } \\
\text { FANCD2 monoubiquitylation }\end{array}$ & - & $\begin{array}{l}\text { Cell and biochemical } \\
\text { tests }\end{array}$ \\
\hline
\end{tabular}


Table 2. Cont.

\begin{tabular}{cccccc}
\hline Name & Target & Origin & Inhibition Mechanisms & Test Diseases & Characteristics \\
\hline miR-548e-5p [262] & UBE2C & $\begin{array}{c}\text { Human LC } \\
\text { organization }\end{array}$ & Binding to the 3'-UTR of UBE2C & NSCLC & In vitro test \\
\hline miR661-3p [263] & UBE2C & Human 293 cells & Binding to the 3'-UTR of UBE2C & NSCLC & $\begin{array}{c}\text { In vivo and in vitro } \\
\text { tests }\end{array}$ \\
\hline miR-381-3p [264] & UBE2C & Human PCa cells & $\begin{array}{c}\text { ICT upregulates the level of miR-381-3p } \\
\text { to downregulate the expression of } \\
\text { UBE2C in human PCa cells }\end{array}$ & PCa & $\begin{array}{c}\text { In vivo and in vitro } \\
\text { tests }\end{array}$ \\
\hline miR-147b [69] & UBE2N & HC organization & Binding to 3'-UTR of UBE2N & HC & $\begin{array}{c}\text { In vivo and in vitro } \\
\text { tests }\end{array}$ \\
\hline miR-1305 [265] & UBE2T & Synthesis & Binding to 3'-UTR of UBE2T & LC & In vivo and in vitro \\
tests
\end{tabular}

In addition to directly targeting the structure of E2s using small molecule inhibitors, the use of miRNAs to inhibit E2 mRNAs might also affect the protein turnover process of cancer cells. miRNAs are endogenous small noncoding RNAs that participate in the regulation of gene expression [267]. miRNAs, as natural antisense nucleotides, showed reduced immune response and low toxicity compared with plasmid DNA-based gene therapy and protein-based drug molecules [268]. However, the low stability of miRNAs and their difficult delivery into cells restrict their application in clinical practice. The delivery of miRNAs combined into nanostructures might improve their biodistribution and accumulation at the target site, with some papers showing encouraging results, both in in vitro and in vivo [269]. miRNA drugs can target molecules that cannot be targeted by chemical drugs or antibody drugs, and are expected to make breakthroughs in cancers with poor efficacy under traditional drugs treatment. Table 2 summarizes the miRNAs that target E2 members, providing a reference for the development of miRNA anticancer drugs.

\section{Concluding Remarks and Future Perspectives}

Through this review, we can see that E2s participate in different biological processes by modifying different molecules, and their abnormal activation or dysfunction might lead to the occurrence and development of cancer. Targeting certain E2 alone might affect a variety of biological processes. For example, the inhibition of UBE2N might affect the NF- $\mathrm{KB}$ pathway involving UBE2V1 and the DNA repair pathway involving UBE2V2. IJ-5 exerts an anti-inflammatory effect by binding to the active cysteine site of UBE2D; however, enzymes such as DUBs, other cysteine proteases, and protein tyrosine phosphatases also have cysteine active sites. Thus, IJ-5 might also inactivate these enzymes.

Based on a wide range of substrates and functions that are affected by E2s, it is necessary to use appropriate in vivo models and genetic methods to study the unique mode of action, functions, and specific modifications performed by a single E2 in different biological environments. Finally, new treatment options will be studied for a single E2, E2 complex, or specific E2-E3 interaction. In addition, it is necessary to understand the relationship between the principle of a drug's action and the pathogenesis of the treated disease, and to develop the best drugs for comprehensive clinical evaluation. The development of drugs is not done overnight. Although some compounds that inhibit E2s are summarized in Table 2, they are limited to experimental studies. Therefore, the development of E2 inhibitors for clinical treatment remains challenging. Specific modifications to the reported E2 inhibitors to reduce these shortcomings, optimize their efficacy, and their use in combined applications (chemotherapy drugs and inhibitors or multi-target inhibitors), might achieve unexpected results.

This article clarifies the molecular basis of E2s as a cancer treatment target and the efforts made to develop E2 inhibitors based on the special position and role of E2s in the 
UPP, the structure of E2s, and the biological processes that E2s participate in. Currently, no E2 inhibitor is actually used in the clinical treatment of cancer; however, its potential as a therapeutic target cannot be ignored. In addition, this review also provides a deeper understanding of the various roles played by E2s in cells and the impact it produces, which could provide a reference for basic research into E2s.

Author Contributions: X.D. wrote the manuscript and prepared the figures and tables. H.S., N.S., R.H. and G.Y. revised the manuscript. All authors have read and agreed to the published version of the manuscript.

Funding: This work was supported by the National Natural Science Foundation of China (grant no. 31672547) and the Key Technology R\&D Program of Sichuan Province, China (no. 2020YFN0030).

Institutional Review Board Statement: Not applicable.

Informed Consent Statement: Not applicable.

Data Availability Statement: Not applicable.

Acknowledgments: We thank Mujeeb Ur Rehman for his grammatical revisions to this review. At the same time, we thank Hong Yang for his suggestions to modify the content of this review.

Conflicts of Interest: The authors declare no conflict of interest.

$\begin{array}{ll}\text { Abbreviations } & \\ \text { ALL } & \text { Acute Lymphoblastic Leukemia } \\ \text { BC } & \text { Breast cancer } \\ \text { BMAL1 } & \text { Brain and muscle arnt-like 1 } \\ \text { C- } & \text { C-terminal } \\ \text { CCN (A/B/D/E) } & \text { Cell cyclin (A/B/D/E) } \\ \text { CDK } & \text { Cyclin-dependent kinase } \\ \text { CLPs } & \text { Common lymphatic progenitor cells } \\ \text { CRLs } & \text { Cullin-RING ligases } \\ \text { DLBCL } & \text { Diffuse large B-cell lymphoma } \\ \text { DUB } & \text { Deubiquitinating enzyme } \\ \text { E2 } & \text { Ubiquitin-conjugating enzyme } \\ \text { EBV } & \text { Epstein-Barr virus } \\ \text { ERAD } & \text { Endoplasmic reticulum-associated degradation } \\ \text { FA } & \text { Fanconi } \\ \text { GBM } & \text { Glioblastoma } \\ \text { HCC } & \text { Hepatocellular carcinoma } \\ \text { HR } & \text { Homologous recombination } \\ \text { ICL } & \text { Interstrand cross-link } \\ \text { IKK } & \text { IkB kinase } \\ \text { LC } & \text { Lung cancer } \\ \text { LUBAC } & \text { Linear ubiquitin chain assembly complex } \\ \text { mES } & \text { Mouse embryonic stem cells } \\ \text { MM } & \text { Multiple myeloma } \\ \text { MMP } & \text { Matrix metalloprotinase } \\ \text { N- } & \text { N-terminal } \\ \text { NF-kB } & \text { Nuclear factor-kappa B } \\ \text { NIK } & \text { NF-kB inducing kinase } \\ \text { NSCLC } & \text { Non-small cell lung cancer } \\ \text { OSCC } & \text { Oral squamous cell carcinoma } \\ \text { PCa } & \text { Prostate cancer } \\ \text { PCNA } & \text { Proliferating cell nuclear antigen } \\ \text { polyUb } & \text { Polyubiquitin } \\ \text { RING } & \text { Really interesting new gene } \\ \text { RPs } & \text { Ribosomal proteins } \\ \text { SCF } & \text { SKP1/CUL1/F-box protein complex } \\ \text { TLS } & \text { Translesion synthesis } \\ \text { TNF- } \alpha & \text { Tumor necrosis factor } \alpha \\ \beta \text { TrCP } & \text { An-transducin repeat-containing protein } \\ \text { Ub } & \text { Ubiquitin } \\ \text { Ubl } & \text { Ub-like } \\ \text { APC/C } & \\ \text { BCL2 } & \text { Anemia/lymphoma 2 } \\ & \end{array}$




\begin{tabular}{ll} 
BRCA1 & Breast cancer 1 \\
CC & Colon cancer \\
CDC20 & Cell division cycle 20 \\
CDKN1A/p21/Cip1 & Cyclin dependent kinase inhibitor 1A \\
CRC & Colorectal cancer \\
DDP & Cisplatin \\
DSBR & DNA Double strand break repair \\
E1 & Ubiquitin activating enzyme \\
E3 & Ubiquitin ligase \\
EMT & Epithelial to mesenchyme transition \\
ERK & Extracellular regulated protein kinases \\
FOXM1 & Forkhead box protein M1 \\
GC & Gastric cancer \\
HNSCC & Head and neck squamous cell carcinoma \\
IAPs & Inhibitor of apoptosis proteins \\
ICT & Icaritin \\
IKB & Inhibitor of nuclear factor kappa B \\
LCSCs & Liver cancer stem cell \\
MDM2 & Mouse double minute 2 homolog \\
miRNAs & microRNAs \\
MMC & Mitomycin C \\
MXI1 & Max-interacting protein 1 \\
NB & Neuroblastoma \\
NHEJ & Non-homologous end joining \\
NPC & Nasopharyngeal carcinoma \\
OC & Ovarian cancer \\
p27Kip1 & Kinase inhibition protein p27 \\
PCGF2 & Polycomb group ring finger 2 \\
PML-RARA & Promyelocytic leukemia (PML) and the retinoic acid receptor- $\alpha$ (RARA) \\
RC & Renal carcinoma \\
RIP1 & Receptor-interacting protein 1 \\
SAC & Spindle-assembly checkpoint \\
SUMO & Small ubiquitin-like modifier \\
TNBC & Triple negative breast cancer \\
TRAF & TNF receptor associated factor \\
TSCC & Tongue Squamous Cell Carcinoma \\
UBC & Ubiquitin-conjugating \\
UPP & Ubiquitin-Proteasome Pathway \\
& \\
\hline &
\end{tabular}

\section{References}

1. Wilkinson, K.D. The discovery of ubiquitin-dependent proteolysis. Proc. Natl. Acad. Sci. USA 2005, 102, 15280-15282. [CrossRef] [PubMed]

2. Hicke, L.; Dunn, R. Regulation of membrane protein transport by ubiquitin and ubiquitin-binding proteins. Annu. Rev. Cell Dev. Biol. 2003, 19, 141-172. [CrossRef] [PubMed]

3. Della Sala, G.; Agriesti, F.; Mazzoccoli, C.; Tataranni, T.; Costantino, V.; Piccoli, C. Clogging the Ubiquitin-Proteasome Machinery with Marine Natural Products: Last Decade Update. Mar. Drugs 2018, 16, 467. [CrossRef] [PubMed]

4. Ye, Y.; Rape, M. Building ubiquitin chains: E2 enzymes at work. Nat. Rev. Mol. Cell Biol. 2009, 10, 755-764. [CrossRef] [PubMed]

5. Ullah, K.; Zubia, E.; Narayan, M.; Yang, J.; Xu, G. Diverse roles of the E2/E3 hybrid enzyme UBE2O in the regulation of protein ubiquitination, cellular functions, and disease onset. FEBS J. 2019, 286, 2018-2034. [CrossRef]

6. Xie, C.; Powell, C.; Yao, M.; Wu, J.; Dong, Q. Ubiquitin-conjugating enzyme E2C: A potential cancer biomarker. Int. J. Biochem. Cell Biol. 2014, 47, 113-117. [CrossRef]

7. Wang, R.; Song, Y.; Liu, X.; Wang, Q.; Wang, Y.; Li, L.; Kang, C.; Zhang, Q. UBE2C induces EMT through Wnt/ $\beta$-catenin and PI3K/Akt signaling pathways by regulating phosphorylation levels of Aurora-A. Int. J. Oncol. 2017, 50, 1116-1126. [CrossRef]

8. Zhang, H.Q.; Zhao, G.; Ke, B.; Ma, G.; Liu, G.L.; Liang, H.; Liu, L.R.; Hao, X.S. Overexpression of UBE2C correlates with poor prognosis in gastric cancer patients. Eur. Rev. Med. Pharmacol. Sci. 2018, 22, 1665-1671. [CrossRef]

9. Yang, M.; Qu, Y.; Shi, R.; Wu, X.; Su, C.; Hu, Z.; Chang, Q.; Liu, S.; Pan, G.; Lei, M.; et al. Ubiquitin-conjugating enzyme UbcH10 promotes gastric cancer growth and is a potential biomarker for gastric cancer. Oncol. Rep. 2016, 36, 779-786. [CrossRef]

10. Van Ree, J.H.; Jeganathan, K.B.; Malureanu, L.; van Deursen, J.M. Overexpression of the E2 ubiquitin-conjugating enzyme UbcH10 causes chromosome missegregation and tumor formation. J. Cell Biol. 2010, 188, 83-100. [CrossRef]

11. Wu, X.; Zhang, W.; Font-Burgada, J.; Palmer, T.; Hamil, A.S.; Biswas, S.K.; Poidinger, M.; Borcherding, N.; Xie, Q.; Ellies, L.G.; et al. Ubiquitin-conjugating enzyme Ubc13 controls breast cancer metastasis through a TAK1-p38 MAP kinase cascade. Proc. Natl. Acad. Sci. USA 2014, 111, 13870-13875. [CrossRef] [PubMed]

12. Zhang, X.; Linder, S.; Bazzaro, M. Drug Development Targeting the Ubiquitin-Proteasome System (UPS) for the Treatment of Human Cancers. Cancers 2020, 12, 902. [CrossRef] [PubMed] 
13. Liu, W.; Tang, X.; Qi, X.; Fu, X.; Ghimire, S.; Ma, R.; Li, S.; Zhang, N.; Si, H. The Ubiquitin Conjugating Enzyme: An Important Ubiquitin Transfer Platform in Ubiquitin-Proteasome System. Int. J. Mol. Sci 2020, 21, 2894. [CrossRef]

14. Xu, F.Q.; Xue, H.W. The ubiquitin-proteasome system in plant responses to environments. Plant. Cell Environ. 2019, 42, 2931-2944. [CrossRef]

15. Sadanandom, A.; Bailey, M.; Ewan, R.; Lee, J.; Nelis, S. The ubiquitin-proteasome system: Central modifier of plant signalling. New Phytol. 2012, 196, 13-28. [CrossRef] [PubMed]

16. Nandi, D.; Tahiliani, P.; Kumar, A.; Chandu, D. The ubiquitin-proteasome system. J. Biosci. 2006, 31, 137-155. [CrossRef] [PubMed]

17. McGinty, R.K.; Henrici, R.C.; Tan, S. Crystal structure of the PRC1 ubiquitylation module bound to the nucleosome. Nature 2014, 514, 591-596. [CrossRef] [PubMed]

18. Pruneda, J.N.; Smith, F.D.; Daurie, A.; Swaney, D.L.; Villén, J.; Scott, J.D.; Stadnyk, A.W.; Le Trong, I.; Stenkamp, R.E.; Klevit, R.E.; et al. E2 Ub conjugates regulate the kinase activity of Shigella effector OspG during pathogenesis. EMBO J. 2014, 33, 437-449. [CrossRef]

19. Spit, M.; Rieser, E.; Walczak, H. Linear ubiquitination at a glance. J. Cell Sci. 2019, 132. [CrossRef]

20. Grice, G.L.; Lobb, I.T.; Weekes, M.P.; Gygi, S.P.; Antrobus, R.; Nathan, J.A. The Proteasome Distinguishes between Heterotypic and Homotypic Lysine-11-Linked Polyubiquitin Chains. Cell Rep. 2015, 12, 545-553. [CrossRef]

21. Damgaard, R.B.; Walker, J.A.; Marco-Casanova, P.; Morgan, N.V.; Titheradge, H.L.; Elliott, P.R.; McHale, D.; Maher, E.R.; McKenzie, A.N.J.; Komander, D. The Deubiquitinase OTULIN Is an Essential Negative Regulator of Inflammation and Autoimmunity. Cell 2016, 166, 1215-1230.e1220. [CrossRef] [PubMed]

22. Meyer, H.J.; Rape, M. Enhanced protein degradation by branched ubiquitin chains. Cell 2014, 157, 910-921. [CrossRef]

23. Haglund, K.; Dikic, I. Ubiquitylation and cell signaling. EMBO J. 2005, 24, 3353-3359. [CrossRef]

24. Kuang, P.; Tan, M.; Zhou, W.; Zhang, Q.; Sun, Y. SAG/RBX2 E3 ligase complexes with UBCH10 and UBE2S E2s to ubiquitylate $\beta$-TrCP1 via K11-linkage for degradation. Sci. Rep. 2016, 6, 37441. [CrossRef] [PubMed]

25. Li, X.; Elmira, E.; Rohondia, S.; Wang, J.; Liu, J.; Dou, Q.P. A patent review of the ubiquitin ligase system: 2015-2018. Expert Opin. Ther. Pat. 2018, 28, 919-937. [CrossRef] [PubMed]

26. Van Wijk, S.J.; Timmers, H.T. The family of ubiquitin-conjugating enzymes (E2s): Deciding between life and death of proteins. FASEB J. 2010, 24, 981-993. [CrossRef]

27. Stewart, M.D.; Ritterhoff, T.; Klevit, R.E.; Brzovic, P.S. E2 enzymes: More than just middle men. Cell Res. 2016, 26, 423-440. [CrossRef] [PubMed]

28. Sancho, E.; Vilá, M.R.; Sánchez-Pulido, L.; Lozano, J.J.; Paciucci, R.; Nadal, M.; Fox, M.; Harvey, C.; Bercovich, B.; Loukili, N.; et al Role of UEV-1, an inactive variant of the E2 ubiquitin-conjugating enzymes, in in vitro differentiation and cell cycle behavior of HT-29-M6 intestinal mucosecretory cells. Mol. Cell Biol. 1998, 18, 576-589. [CrossRef] [PubMed]

29. Wenzel, D.M.; Stoll, K.E.; Klevit, R.E. E2s: Structurally economical and functionally replete. Biochem. J. 2011, 433, 31-42. [CrossRef] [PubMed]

30. Hormaechea-Agulla, D.; Kim, Y.; Song, M.S.; Song, S.J. New Insights into the Role of E2s in the Pathogenesis of Diseases: Lessons Learned from UBE2O. Mol. Cells 2018, 41, 168-178. [CrossRef]

31. Garg, P.; Ceccarelli, D.F.; Keszei, A.F.A.; Kurinov, I.; Sicheri, F.; Sidhu, S.S. Structural and Functional Analysis of Ubiquitin-based Inhibitors That Target the Backsides of E2 Enzymes. J. Mol. Biol. 2020, 432, 952-966. [CrossRef]

32. Cappadocia, L.; Lima, C.D. Ubiquitin-like Protein Conjugation: Structures, Chemistry, and Mechanism. Chem. Rev. 2018, 118, 889-918. [CrossRef]

33. Hosseini, S.M.; Okoye, I.; Chaleshtari, M.G.; Hazhirkarzar, B.; Mohamadnejad, J.; Azizi, G.; Hojjat-Farsangi, M.; Mohammadi, H.; Shotorbani, S.S.; Jadidi-Niaragh, F. E2 ubiquitin-conjugating enzymes in cancer: Implications for immunotherapeutic interventions. Clin. Chim. Acta 2019, 498, 126-134. [CrossRef]

34. Magistroni, V.; Mauri, M.; D’Aliberti, D.; Mezzatesta, C.; Crespiatico, I.; Nava, M.; Fontana, D.; Sharma, N.; Parker, W.; Schreiber, A.; et al. De novo $U B E 2 A$ mutations are recurrently acquired during chronic myeloid leukemia progression and interfere with myeloid differentiation pathways. Haematologica 2019, 104, 1789-1797. [CrossRef]

35. Wang, L.; Chen, Y.J.; Hou, J.; Wang, Y.Y.; Tang, W.Q.; Shen, X.Z.; Tu, R.Q. Expression and clinical significance of BIRC6 in human epithelial ovarian cancer. Tumour Biol. 2014, 35, 4891-4896. [CrossRef]

36. Liu, G.; Zhao, J.; Pan, B.; Ma, G.; Liu, L. UBE2C overexpression in melanoma and its essential role in G2/M transition. J. Cancer 2019, 10, 2176-2184. [CrossRef]

37. Wei, Z.; Liu, Y.; Qiao, S.; Li, X.; Li, Q.; Zhao, J.; Hu, J.; Wei, Z.; Shan, A.; Sun, X.; et al. Identification of the potential therapeutic target gene UBE2C in human hepatocellular carcinoma: An investigation based on GEO and TCGA databases. Oncol. Lett. 2019, 17, 5409-5418. [CrossRef]

38. Jin, Z.; Zhao, X.; Cui, L.; Xu, X.; Zhao, Y.; Younai, F.; Messadi, D.; Hu, S. UBE2C promotes the progression of head and neck squamous cell carcinoma. Biochem. Biophys. Res. Commun. 2020, 523, 389-397. [CrossRef]

39. Cacciola, N.A.; Calabrese, C.; Malapelle, U.; Pellino, G.; De Stefano, A.; Sepe, R.; Sgariglia, R.; Quintavalle, C.; Federico, A.; Bianco, A.; et al. UbcH10 expression can predict prognosis and sensitivity to the antineoplastic treatment for colorectal cancer patients. Mol. Carcinog. 2016, 55, 793-807. [CrossRef]

40. Ma, R.; Kang, X.; Zhang, G.; Fang, F.; Du, Y.; Lv, H. High expression of UBE2C is associated with the aggressive progression and poor outcome of malignant glioma. Oncol. Lett. 2016, 11, 2300-2304. [CrossRef] 
41. Liu, P.F.; Chen, C.F.; Shu, C.W.; Chang, H.M.; Lee, C.H.; Liou, H.H.; Ger, L.P.; Chen, C.L.; Kang, B.H. UBE2C is a Potential Biomarker for Tumorigenesis and Prognosis in Tongue Squamous Cell Carcinoma. Diagnostics 2020, 10, 674. [CrossRef]

42. Zhang, Z.; Liu, P.; Wang, J.; Gong, T.; Zhang, F.; Ma, J.; Han, N. Ubiquitin-conjugating enzyme E2C regulates apoptosis-dependent tumor progression of non-small cell lung cancer via ERK pathway. Med. Oncol. 2015, 32, 149. [CrossRef]

43. Li, J.; Zhi, X.; Shen, X.; Chen, C.; Yuan, L.; Dong, X.; Zhu, C.; Yao, L.; Chen, M. Depletion of UBE2C reduces ovarian cancer malignancy and reverses cisplatin resistance via downregulating CDK1. Biochem. Biophys. Res. Commun. 2020, 523, 434-440. [CrossRef]

44. Lee, J.Y.; Tokumoto, M.; Fujiwara, Y.; Hasegawa, T.; Seko, Y.; Shimada, A.; Satoh, M. Accumulation of p53 via down-regulation of UBE2D family genes is a critical pathway for cadmium-induced renal toxicity. Sci. Rep. 2016, 6, 21968. [CrossRef]

45. Guan, G.G.; Wang, W.B.; Lei, B.X.; Wang, Q.L.; Wu, L.; Fu, Z.M.; Zhou, F.X.; Zhou, Y.F. UBE2D3 is a positive prognostic factor and is negatively correlated with hTERT expression in esophageal cancer. Oncol. Lett. 2015, 9, 1567-1574. [CrossRef]

46. Luo, H.; Qin, Y.; Reu, F.; Ye, S.; Dai, Y.; Huang, J.; Wang, F.; Zhang, D.; Pan, L.; Zhu, H.; et al. Microarray-based analysis and clinical validation identify ubiquitin-conjugating enzyme E2E1 (UBE2E1) as a prognostic factor in acute myeloid leukemia. $J$. Hematol. Oncol. 2016, 9, 125. [CrossRef]

47. Desai, S.D.; Reed, R.E.; Burks, J.; Wood, L.M.; Pullikuth, A.K.; Haas, A.L.; Liu, L.F.; Breslin, J.W.; Meiners, S.; Sankar, S. ISG15 disrupts cytoskeletal architecture and promotes motility in human breast cancer cells. Exp. Biol. Med. 2012, 237, 38-49. [CrossRef]

48. Plafker, K.S.; Zyla, K.; Berry, W.; Plafker, S.M. Loss of the ubiquitin conjugating enzyme UBE2E3 induces cellular senescence. Redox Biol. 2018, 17, 411-422. [CrossRef]

49. Debonneville, C.; Staub, O. Participation of the ubiquitin-conjugating enzyme UBE2E3 in Nedd4-2-dependent regulation of the epithelial Na+ channel. Mol. Cell Biol. 2004, 24, 2397-2409. [CrossRef]

50. Liu, R.; Cheng, Q.; Song, X.; Wang, H.; Wang, X.; Wang, L.; Zhu, B.; Song, L. A vital ubiquitin-conjugating enzyme CgUbe2g1 participated in regulation of immune response of Pacific oyster Crassostrea gigas. Dev. Comp. Immunol. 2019, 91, 132-142. [CrossRef]

51. Lu, G.; Weng, S.; Matyskiela, M.; Zheng, X.; Fang, W.; Wood, S.; Surka, C.; Mizukoshi, R.; Lu, C.C.; Mendy, D.; et al. UBE2G1 governs the destruction of cereblon neomorphic substrates. eLife 2018, 7. [CrossRef]

52. Van de Weijer, M.L.; Schuren, A.B.C.; van den Boomen, D.J.H.; Mulder, A.; Claas, F.H.J.; Lehner, P.J.; Lebbink, R.J.; Wiertz, E. Multiple E2 ubiquitin-conjugating enzymes regulate human cytomegalovirus US2-mediated immunoreceptor downregulation. $J$. Cell Sci. 2017, 130, 2883-2892. [CrossRef]

53. Zhao, X.; Yongchun, Z.; Qian, H.; Sanhui, G.; Jie, L.; Hong, Y.; Yanfei, Z.; Guizhen, W.; Yunchao, H.; Guangbiao, Z. Identification of a potential tumor suppressor gene, UBL3, in non-small cell lung cancer. Cancer Biol. Med. 2020, 17, 76-87. [CrossRef]

54. Chen, Z.; Hu, H. Identification of prognosis biomarkers of prostatic cancer in a cohort of 498 patients from TCGA. Curr. Probl. Cancer 2019, 43, 100503. [CrossRef]

55. Vourc'h, P.; Martin, I.; Bonnet-Brilhault, F.; Marouillat, S.; Barthélémy, C.; Pierre Müh, J.; Andres, C. Mutation screening and association study of the UBE2H gene on chromosome 7q32 in autistic disorder. Psychiatry Genet. 2003, 13, 221-225. [CrossRef]

56. Li, Y.P.; Lecker, S.H.; Chen, Y.; Waddell, I.D.; Goldberg, A.L.; Reid, M.B. TNF-alpha increases ubiquitin-conjugating activity in skeletal muscle by up-regulating UbcH2/E220k. FASEB J. 2003, 17, 1048-1057. [CrossRef] [PubMed]

57. Feng, T.; Deng, L.; Lu, X.; Pan, W.; Wu, Q.; Dai, J. Ubiquitin-conjugating enzyme UBE2J1 negatively modulates interferon pathway and promotes RNA virus infection. Virol. J. 2018, 15, 132. [CrossRef]

58. Palmer, C.J.; Galan-Caridad, J.M.; Weisberg, S.P.; Lei, L.; Esquilin, J.M.; Croft, G.F.; Wainwright, B.; Canoll, P.; Owens, D.M.; Reizis, B. Zfx facilitates tumorigenesis caused by activation of the Hedgehog pathway. Cancer Res. 2014, 74, 5914-5924. [CrossRef]

59. Chen, S.; Tan, Y.; Deng, H.; Shen, Z.; Liu, Y.; Wu, P.; Tan, C.; Jiang, Y. UBE2J2 promotes hepatocellular carcinoma cell epithelialmesenchymal transition and invasion in vitro. Oncotarget 2017, 8, 71736-71749. [CrossRef] [PubMed]

60. Tao, N.N.; Zhang, Z.Z.; Ren, J.H.; Zhang, J.; Zhou, Y.J.; Wai Wong, V.K.; Kwan Law, B.Y.; Cheng, S.T.; Zhou, H.Z.; Chen, W.X.; et al. Overexpression of ubiquitin-conjugating enzyme E2 L3 in hepatocellular carcinoma potentiates apoptosis evasion by inhibiting the GSK3 $\beta /$ p65 pathway. Cancer Lett. 2020, 481, 1-14. [CrossRef]

61. Yi, S.A.; Kim, G.W.; Yoo, J.; Han, J.W.; Kwon, S.H. HP1 $\gamma$ Sensitizes Cervical Cancer Cells to Cisplatin through the Suppression of UBE2L3. Int. J. Mol. Sci. 2020, 21, 5976. [CrossRef]

62. Ma, X.; Zhao, J.; Yang, F.; Liu, H.; Qi, W. Ubiquitin conjugating enzyme E2 L3 promoted tumor growth of NSCLC through accelerating p27kip1 ubiquitination and degradation. Oncotarget 2017, 8, 84193-84203. [CrossRef]

63. Whitcomb, E.A.; Tsai, Y.C.; Basappa, J.; Liu, K.; Le Feuvre, A.K.; Weissman, A.M.; Taylor, A. Stabilization of p27(Kip1)/CDKN1B by UBCH7/UBE2L3 catalyzed ubiquitinylation: A new paradigm in cell-cycle control. FASEB J. 2019, 33, 1235-1247. [CrossRef] [PubMed]

64. Fu, B.; Li, S.; Wang, L.; Berman, M.A.; Dorf, M.E. The ubiquitin conjugating enzyme UBE2L3 regulates TNF $\alpha$-induced linear ubiquitination. Cell Res. 2014, 24, 376-379. [CrossRef]

65. Alpi, A.F.; Chaugule, V.; Walden, H. Mechanism and disease association of E2-conjugating enzymes: Lessons from UBE2T and UBE2L3. Biochem. J. 2016, 473, 3401-3419. [CrossRef] [PubMed]

66. Hodge, C.D.; Edwards, R.A.; Markin, C.J.; McDonald, D.; Pulvino, M.; Huen, M.S.; Zhao, J.; Spyracopoulos, L.; Hendzel, M.J.; Glover, J.N. Covalent Inhibition of Ubc13 Affects Ubiquitin Signaling and Reveals Active Site Elements Important for Targeting. ACS Chem. Biol. 2015, 10, 1718-1728. [CrossRef] 
67. Song, T.T.; Xu, F.; Wang, W. Inhibiting ubiquitin conjugating enzyme E2 $N$ by microRNA-590-3p reduced cell growth of cervical carcinoma. Kaohsiung J. Med. Sci. 2020, 36, 501-507. [CrossRef]

68. Zhang, E.; Liu, Q.; Wang, Y.; Wang, H.; He, L.; Jin, X.; Li, N. MicroRNA miR-147b promotes tumor growth via targeting UBE2N in hepatocellular carcinoma. Oncotarget 2017, 8, 114072-114080. [CrossRef]

69. Dikshit, A.; Jin, Y.J.; Degan, S.; Hwang, J.; Foster, M.W.; Li, C.Y.; Zhang, J.Y. UBE2N Promotes Melanoma Growth via MEK/FRA1/SOX10 Signaling. Cancer Res. 2018, 78, 6462-6472. [CrossRef]

70. Shen, T.; Cai, L.D.; Liu, Y.H.; Li, S.; Gan, W.J.; Li, X.M.; Wang, J.R.; Guo, P.D.; Zhou, Q.; Lu, X.X.; et al. Ube2v1-mediated ubiquitination and degradation of Sirt1 promotes metastasis of colorectal cancer by epigenetically suppressing autophagy. $J$. Hematol. Oncol. 2018, 11, 95. [CrossRef]

71. Chen, S.; Yang, J.; Zhang, Y.; Duan, C.; Liu, Q.; Huang, Z.; Xu, Y.; Zhou, L.; Xu, G. Ubiquitin-conjugating enzyme UBE2O regulates cellular clock function by promoting the degradation of the transcription factor BMAL1. J. Biol. Chem. 2018, 293, 11296-11309. [CrossRef]

72. Liu, X.; Ma, F.; Liu, C.; Zhu, K.; Li, W.; Xu, Y.; Li, G.; Niu, Z.; Liu, J.; Chen, D.; et al. UBE2O promotes the proliferation, EMT and stemness properties of breast cancer cells through the UBE2O/AMPK $\alpha 2 / \mathrm{mTORC1-MYC} \mathrm{positive} \mathrm{feedback} \mathrm{loop.} \mathrm{Cell} \mathrm{Death} \mathrm{Dis.}$ 2020, 11, 10. [CrossRef]

73. Chen, X.; Zhang, S.; Liu, C.; Li, G.; Lu, S.; Wang, Y.; Zhang, X.; Huang, D.; Qiu, Y.; Liu, Y. UBE2O Promotes Progression and Epithelial-Mesenchymal Transition in Head and Neck Squamous Cell Carcinoma. OncoTargets Ther. 2020, 13, 6191-6202. [CrossRef]

74. Huang, Y.; Yang, X.; Lu, Y.; Zhao, Y.; Meng, R.; Zhang, S.; Dong, X.; Xu, S.; Wu, G. UBE2O targets Mxi1 for ubiquitination and degradation to promote lung cancer progression and radioresistance. Cell Death Differ. 2021, 28, 671-684. [CrossRef]

75. Nguyen, A.T.; Prado, M.A.; Schmidt, P.J.; Sendamarai, A.K.; Wilson-Grady, J.T.; Min, M.; Campagna, D.R.; Tian, G.; Shi, Y.; Dederer, V.; et al. UBE2O remodels the proteome during terminal erythroid differentiation. Science 2017, 357. [CrossRef]

76. Zhang, X.; Zhang, J.; Bauer, A.; Zhang, L.; Selinger, D.W.; Lu, C.X.; Ten Dijke, P. Fine-tuning BMP7 signalling in adipogenesis by UBE2O/E2-230K-mediated monoubiquitination of SMAD6. EMBO J. 2013, 32, 996-1007. [CrossRef]

77. Shafiee, S.M.; Rasti, M.; Seghatoleslam, A.; Azimi, T.; Owji, A.A. UBE2Q1 in a Human Breast Carcinoma Cell Line: Overexpression and Interaction with p53. Asian Pac. J. Cancer Prev. 2015, 16, 3723-3727. [CrossRef]

78. Seghatoleslam, A.; Bozorg-Ghalati, F.; Monabati, A.; Nikseresht, M.; Owji, A.A. UBE2Q1, as a Down Regulated Gene in Pediatric Acute Lymphoblastic Leukemia. Int. J. Mol. Cell Med. 2014, 3, 95-101.

79. Shafiee, S.M.; Seghatoleslam, A.; Nikseresht, M.; Hosseini, S.V.; Alizadeh-Naeeni, M.; Safaei, A.; Owji, A.A. UBE2Q1 expression in human colorectal tumors and cell lines. Mol. Biol. Rep. 2013, 40, 7045-7051. [CrossRef]

80. Kravic, B.; Behrends, C.; Meyer, H. Regulation of lysosome integrity and lysophagy by the ubiquitin-conjugating enzyme UBE2QL1. Autophagy 2020, 16, 179-180. [CrossRef]

81. Maeda, H.; Miyajima, N.; Kano, S.; Tsukiyama, T.; Okumura, F.; Fukuda, S.; Hatakeyama, S. Ubiquitin-conjugating enzyme UBE2Q2 suppresses cell proliferation and is down-regulated in recurrent head and neck cancer. Mol. Cancer Res. 2009, 7, 1553-1562. [CrossRef]

82. Shafiee, S.M.; Seghatoleslam, A.; Nikseresht, M.; Hosseini, S.V.; Alizadeh-Naeeni, M.; Safaei, A.; Owji, A.A. Expression Status of UBE2Q2 in Colorectal Primary Tumors and Cell Lines. Iran. J. Med. Sci. 2014, 39, 196-202.

83. Williams, K.M.; Qie, S.; Atkison, J.H.; Salazar-Arango, S.; Alan Diehl, J.; Olsen, S.K. Structural insights into E1 recognition and the ubiquitin-conjugating activity of the E2 enzyme Cdc34. Nat. Commun. 2019, 10, 3296. [CrossRef]

84. Liu, X.; Zhang, Y.; Hu, Z.; Li, Q.; Yang, L.; Xu, G. The Catalytically Inactive Mutation of the Ubiquitin-Conjugating Enzyme CDC34 Affects its Stability and Cell Proliferation. Protein J. 2018, 37, 132-143. [CrossRef]

85. Zhao, X.C.; Wang, G.Z.; Wen, Z.S.; Zhou, Y.C.; Hu, Q.; Zhang, B.; Qu, L.W.; Gao, S.H.; Liu, J.; Ma, L.; et al. Systematic identification of CDC34 that functions to stabilize EGFR and promote lung carcinogenesis. eBioMedicine 2020, 53, 102689. [CrossRef]

86. Eliseeva, E.; Pati, D.; Diccinanni, M.B.; Yu, A.L.; Mohsin, S.K.; Margolin, J.F.; Plon, S.E. Expression and localization of the CDC34 ubiquitin-conjugating enzyme in pediatric acute lymphoblastic leukemia. Cell Growth Differ. 2001, 12, 427-433.

87. Yoshimura, S.; Kasamatsu, A.; Nakashima, D.; Iyoda, M.; Kasama, H.; Saito, T.; Takahara, T.; Endo-Sakamoto, Y.; Shiiba, M.; Tanzawa, H.; et al. UBE2S associated with OSCC proliferation by promotion of P21 degradation via the ubiquitin-proteasome system. Biochem. Biophys. Res. Commun. 2017, 485, 820-825. [CrossRef]

88. Ayesha, A.K.; Hyodo, T.; Asano, E.; Sato, N.; Mansour, M.A.; Ito, S.; Hamaguchi, M.; Senga, T. UBE2S is associated with malignant characteristics of breast cancer cells. Tumour Biol. 2016, 37, 763-772. [CrossRef]

89. Wang, J.; Zhang, Y.; Hou, J.; Qian, X.; Zhang, H.; Zhang, Z.; Li, M.; Wang, R.; Liao, K.; Wang, Y.; et al. Ube2s regulates Sox2 stability and mouse ES cell maintenance. Cell Death Differ. 2016, 23, 393-404. [CrossRef]

90. Kelsall, I.R.; Langenick, J.; MacKay, C.; Patel, K.J.; Alpi, A.F. The Fanconi anaemia components UBE2T and FANCM are functionally linked to nucleotide excision repair. PLoS ONE 2012, 7, e36970. [CrossRef]

91. Hira, A.; Yoshida, K.; Sato, K.; Okuno, Y.; Shiraishi, Y.; Chiba, K.; Tanaka, H.; Miyano, S.; Shimamoto, A.; Tahara, H.; et al. Mutations in the gene encoding the E2 conjugating enzyme UBE2T cause Fanconi anemia. Am. J. Hum. Genet. 2015, 96, 1001-1007. [CrossRef]

92. Yu, H.; Xiang, P.; Pan, Q.; Huang, Y.; Xie, N.; Zhu, W. Ubiquitin-Conjugating Enzyme E2T is an Independent Prognostic Factor and Promotes Gastric Cancer Progression. Tumour Biol. 2016, 37, 11723-11732. [CrossRef] 
93. Wang, Y.; Leng, H.; Chen, H.; Wang, L.; Jiang, N.; Huo, X.; Yu, B. Knockdown of UBE2T Inhibits Osteosarcoma Cell Proliferation, Migration, and Invasion by Suppressing the PI3K/Akt Signaling Pathway. Oncol Res. 2016, 24, 361-369. [CrossRef] [PubMed]

94. Wen, M.; Kwon, Y.; Wang, Y.; Mao, J.H.; Wei, G. Elevated expression of UBE2T exhibits oncogenic properties in human prostate cancer. Oncotarget 2015, 6, 25226-25239. [CrossRef]

95. Wu, Z.H.; Zhang, Y.J.; Sun, H.Y. High ubiquitin conjugating enzyme E2 T mRNA expression and its prognostic significance in lung adenocarcinoma: A study based on the TCGA database. Medicine 2020, 99, e18543. [CrossRef]

96. Perez-Peña, J.; Corrales-Sánchez, V.; Amir, E.; Pandiella, A.; Ocana, A. Ubiquitin-conjugating enzyme E2T (UBE2T) and denticleless protein homolog (DTL) are linked to poor outcome in breast and lung cancers. Sci. Rep. 2017, 7, 17530. [CrossRef]

97. Liu, L.L.; Zhu, J.M.; Yu, X.N.; Zhu, H.R.; Shi, X.; Bilegsaikhan, E.; Guo, H.Y.; Wu, J.; Shen, X.Z. UBE2T promotes proliferation via G2/M checkpoint in hepatocellular carcinoma. Cancer Manag. Res. 2019, 11, 8359-8370. [CrossRef]

98. Yu, H.; Wang, H.; Dong, W.; Cao, Z.Y.; Li, R.; Yang, C.; Cong, W.M.; Dong, H.; Jin, G.Z. The diagnostic and prognostic value of UBE2T in intrahepatic cholangiocarcinoma. Peer] 2020, 8, e8454. [CrossRef] [PubMed]

99. Zhu, X.; Li, T.; Niu, X.; Chen, L.; Ge, C. Identification of UBE2T as an independent prognostic biomarker for gallbladder cancer. Oncol. Lett. 2020, 20, 44. [CrossRef]

100. Zhang, W.; Zhang, Y.; Yang, Z.; Liu, X.; Yang, P.; Wang, J.; Hu, K.; He, X.; Zhang, X.; Jing, H. High expression of UBE2T predicts poor prognosis and survival in multiple myeloma. Cancer Gene Ther. 2019, 26, 347-355. [CrossRef]

101. Zou, R.; Xu, H.; Li, F.; Wang, S.; Zhu, L. Increased Expression of UBE2T Predicting Poor Survival of Epithelial Ovarian Cancer: Based on Comprehensive Analysis of UBE2s, Clinical Samples, and the GEO Database. DNA Cell Biol. 2021, 40, 36-60. [CrossRef]

102. Liu, L.P.; Yang, M.; Peng, Q.Z.; Li, M.Y.; Zhang, Y.S.; Guo, Y.H.; Chen, Y.; Bao, S.Y. UBE2T promotes hepatocellular carcinoma cell growth via ubiquitination of p53. Biochem. Biophys. Res. Commun. 2017, 493, 20-27. [CrossRef]

103. Zhang, W.; Zhuang, Y.; Zhang, Y.; Yang, X.; Zhang, H.; Wang, G.; Yin, W.; Wang, R.; Zhang, Z.; Xiao, W. Uev1A facilitates osteosarcoma differentiation by promoting Smurf1-mediated Smad1 ubiquitination and degradation. Cell Death Dis. 2017, 8 , e2974. [CrossRef]

104. Lei, B.; Xie, L.; Zhang, S.; Lv, D.; Shu, F.; Deng, Y. UBE2W down-regulation promotes cell apoptosis and correlates with hypospermatogenesis. Andrologia 2020, 52, e13474. [CrossRef]

105. Ikeda, F. The anti-apoptotic ubiquitin conjugating enzyme BIRC6/BRUCE regulates autophagosome-lysosome fusion. Autophagy 2018, 14, 1283-1284. [CrossRef]

106. Tang, W.; Xue, R.; Weng, S.; Wu, J.; Fang, Y.; Wang, Y.; Ji, L.; Hu, T.; Liu, T.; Huang, X.; et al. BIRC6 promotes hepatocellular carcinogenesis: Interaction of BIRC6 with p53 facilitating p53 degradation. Int. J. Cancer 2015, 136, E475-E487. [CrossRef]

107. Yang, G.; Wang, X.; Liu, B.; Lu, Z.; Xu, Z.; Xiu, P.; Liu, Z.; Li, J. circ-BIRC6, a circular RNA, promotes hepatocellular carcinoma progression by targeting the miR-3918/Bcl2 axis. Cell Cycle 2019, 18, 976-989. [CrossRef]

108. Lamers, F.; Schild, L.; Koster, J.; Speleman, F.; Øra, I.; Westerhout, E.M.; van Sluis, P.; Versteeg, R.; Caron, H.N.; Molenaar, J.J. Identification of BIRC6 as a novel intervention target for neuroblastoma therapy. BMC Cancer 2012, 12, 285. [CrossRef]

109. Zhuang, W.; Zhang, C.; Hao, F.; Sun, X. Baculoviral IAP Repeat Containing 6 (BIRC6) Is a Predictor of Prognosis in Prostate Cancer. Med. Sci. Monit. 2018, 24, 839-845. [CrossRef]

110. Zhou, W.; Xu, J.; Li, H.; Xu, M.; Chen, Z.J.; Wei, W.; Pan, Z.; Sun, Y. Neddylation E2 UBE2F Promotes the Survival of Lung Cancer Cells by Activating CRL5 to Degrade NOXA via the K11 Linkage. Clin. Cancer Res. 2017, 23, 1104-1116. [CrossRef]

111. Wang, A.; Ding, X.; Demarque, M.; Liu, X.; Pan, D.; Xin, H.; Zhong, B.; Wang, X.; Dejean, A.; Jin, W.; et al. Ubc9 Is Required for Positive Selection and Late-Stage Maturation of Thymocytes. J. Immunol. 2017, 198, 3461-3470. [CrossRef]

112. Wang, F.; Sun, F.; Luo, J.; Yue, T.; Chen, L.; Zhou, H.; Zhang, J.; Yang, C.; Luo, X.; Zhou, Q.; et al. Loss of ubiquitin-conjugating enzyme E2 (Ubc9) in macrophages exacerbates multiple low-dose streptozotocin-induced diabetes by attenuating M2 macrophage polarization. Cell Death Dis. 2019, 10, 892. [CrossRef] [PubMed]

113. Varadaraj, A.; Mattoscio, D.; Chiocca, S. SUMO Ubc9 enzyme as a viral target. IUBMB Life 2014, 66, 27-33. [CrossRef]

114. Fang, S.; Qiu, J.; Wu, Z.; Bai, T.; Guo, W. Down-regulation of UBC9 increases the sensitivity of hepatocellular carcinoma to doxorubicin. Oncotarget 2017, 8, 49783-49795. [CrossRef] [PubMed]

115. Zong, Y.; Wu, P.; Nai, C.; Luo, Y.; Hu, F.; Gao, W.; Zhai, N.; Xu, T.; Li, D. Effect of MicroRNA-30e on the Behavior of Vascular Smooth Muscle Cells via Targeting Ubiquitin-Conjugating Enzyme E2I. Circ. J. 2017, 81, 567-576. [CrossRef]

116. McManus, F.P.; Bourdeau, V.; Acevedo, M.; Lopes-Paciencia, S.; Mignacca, L.; Lamoliatte, F.; Rojas Pino, J.W.; Ferbeyre, G.; Thibault, P. Quantitative SUMO proteomics reveals the modulation of several PML nuclear body associated proteins and an anti-senescence function of UBC9. Sci. Rep. 2018, 8, 7754. [CrossRef]

117. Lu, Z.; Wu, H.; Mo, Y.Y. Regulation of bcl-2 expression by Ubc9. Exp. Cell Res. 2006, 312, 1865-1875. [CrossRef]

118. Jo, S.; Lee, Y.L.; Kim, S.; Lee, H.; Chung, H. PCGF2 negatively regulates arsenic trioxide-induced PML-RARA protein degradation via UBE2I inhibition in NB4 cells. Biochim. Biophys. Acta 2016, 1863, 1499-1509. [CrossRef]

119. Edrees, M.A.H.; Luo, J.; Sun, F.; Wang, F.; He, L.; Yue, T.; Chen, L.; Zhang, J.; Zhou, H.; Yang, C.; et al. Ubc9 deficiency selectively impairs the functionality of common lymphoid progenitors (CLPs) during bone marrow hematopoiesis. Mol. Immunol. 2019, 114, 314-322. [CrossRef]

120. Cukras, S.; Morffy, N.; Ohn, T.; Kee, Y. Inactivating UBE2M impacts the DNA damage response and genome integrity involving multiple cullin ligases. PLoS ONE 2014, 9, e101844. [CrossRef] 
121. Zhang, G.C.; Yu, X.N.; Sun, J.L.; Xiong, J.; Yang, Y.J.; Jiang, X.M.; Zhu, J.M. UBE2M promotes cell proliferation via the $\beta$ catenin/cyclin D1 signaling in hepatocellular carcinoma. Aging 2020, 12, 2373-2392. [CrossRef] [PubMed]

122. Xu, B.; Deng, Y.; Bi, R.; Guo, H.; Shu, C.; Shah, N.K.; Chang, J.; Liu, G.; Du, Y.; Wei, W.; et al. A first-in-class inhibitor, MLN4924 (pevonedistat), induces cell-cycle arrest, senescence, and apoptosis in human renal cell carcinoma by suppressing UBE2M-dependent neddylation modification. Cancer Chemother. Pharmacol. 2018, 81, 1083-1093. [CrossRef]

123. Zhao, B.; Gao, C.; Shi, D.; Mao, J.; Zhao, J.; Guo, L.; Guo, J.; Jiao, Z. Knockdown of Nedd8-conjugating enzyme UBE2M suppresses the proliferation and induces the apoptosis of intrahepatic cholangiocarcinoma cells. Oncol. Rep. 2019, 42, 2670-2679. [CrossRef]

124. Zhou, W.; Xu, J.; Tan, M.; Li, H.; Li, H.; Wei, W.; Sun, Y. UBE2M Is a Stress-Inducible Dual E2 for Neddylation and Ubiquitylation that Promotes Targeted Degradation of UBE2F. Mol. Cell 2018, 70, 1008-1024.e1006. [CrossRef]

125. Li, L.; Kang, J.; Zhang, W.; Cai, L.; Wang, S.; Liang, Y.; Jiang, Y.; Liu, X.; Zhang, Y.; Ruan, H.; et al. Validation of NEDD8-conjugating enzyme UBC12 as a new therapeutic target in lung cancer. eBioMedicine 2019, 45, 81-91. [CrossRef]

126. Shi, X.; Wang, B.; Chen, X.; Zheng, Y.; Ding, Y.; Wang, C. Upregulation of ubiquitin-conjugating enzyme E2Z is associated with human hepatocellular carcinoma. Biochem. Biophys. Res. Commun. 2020, 523, 25-32. [CrossRef]

127. Hofmann, K. Ubiquitin-binding domains and their role in the DNA damage response. DNA Repair 2009, 8, 544-556. [CrossRef]

128. Akita, M.; Tak, Y.S.; Shimura, T.; Matsumoto, S.; Okuda-Shimizu, Y.; Shimizu, Y.; Nishi, R.; Saitoh, H.; Iwai, S.; Mori, T.; et al. SUMOylation of xeroderma pigmentosum group $\mathrm{C}$ protein regulates DNA damage recognition during nucleotide excision repair. Sci. Rep. 2015, 5, 10984. [CrossRef]

129. Sun, Y.; Miller Jenkins, L.M.; Su, Y.P.; Nitiss, K.C.; Nitiss, J.L.; Pommier, Y. A conserved SUMO pathway repairs topoisomerase DNA-protein cross-links by engaging ubiquitin-mediated proteasomal degradation. Sci. Adv. 2020, 6. [CrossRef]

130. Kaiser, P.; Mansour, H.A.; Greeten, T.; Auer, B.; Schweiger, M.; Schneider, R. The human ubiquitin-conjugating enzyme UbcH1 is involved in the repair of UV-damaged, alkylated and cross-linked DNA. FEBS Lett. 1994, 350, 1-4. [CrossRef]

131. Roos, W.P.; Thomas, A.D.; Kaina, B. DNA damage and the balance between survival and death in cancer biology. Nat. Rev. Cancer 2016, 16, 20-33. [CrossRef]

132. Torres-Ramos, C.A.; Prakash, S.; Prakash, L. Requirement of RAD5 and MMS2 for postreplication repair of UV-damaged DNA in Saccharomyces cerevisiae. Mol. Cell Biol. 2002, 22, 2419-2426. [CrossRef]

133. Hoege, C.; Pfander, B.; Moldovan, G.L.; Pyrowolakis, G.; Jentsch, S. RAD6-dependent DNA repair is linked to modification of PCNA by ubiquitin and SUMO. Nature 2002, 419, 135-141. [CrossRef]

134. Lentucci, C.; Belkina, A.C.; Cederquist, C.T.; Chan, M.; Johnson, H.E.; Prasad, S.; Lopacinski, A.; Nikolajczyk, B.S.; Monti, S.; Snyder-Cappione, J.; et al. Inhibition of Ubc13-mediated Ubiquitination by GPS2 Regulates Multiple Stages of B Cell Development. J. Biol. Chem. 2017, 292, 2754-2772. [CrossRef]

135. Burma, S.; Chen, B.P.; Chen, D.J. Role of non-homologous end joining (NHEJ) in maintaining genomic integrity. DNA Repair 2006, 5, 1042-1048. [CrossRef]

136. Hu, L.; Li, X.; Liu, Q.; Xu, J.; Ge, H.; Wang, Z.; Wang, H.; Wang, Z.; Shi, C.; Xu, X.; et al. UBE2S, a novel substrate of Akt1, associates with $\mathrm{Ku} 70$ and regulates DNA repair and glioblastoma multiforme resistance to chemotherapy. Oncogene 2017, 36, 1145-1156. [CrossRef]

137. An, H.; Yang, L.; Wang, C.; Gan, Z.; Gu, H.; Zhang, T.; Huang, X.; Liu, Y.; Li, Y.; Chang, S.J.; et al. Interactome Analysis Reveals a Novel Role for RAD6 in the Regulation of Proteasome Activity and Localization in Response to DNA Damage. Mol. Cell Biol. 2017, 37. [CrossRef] [PubMed]

138. Machida, Y.J.; Machida, Y.; Chen, Y.; Gurtan, A.M.; Kupfer, G.M.; D'Andrea, A.D.; Dutta, A. UBE2T is the E2 in the Fanconi anemia pathway and undergoes negative autoregulation. Mol. Cell 2006, 23, 589-596. [CrossRef]

139. Nijman, S.M.; Huang, T.T.; Dirac, A.M.; Brummelkamp, T.R.; Kerkhoven, R.M.; D'Andrea, A.D.; Bernards, R. The deubiquitinating enzyme USP1 regulates the Fanconi anemia pathway. Mol. Cell 2005, 17, 331-339. [CrossRef] [PubMed]

140. Mamrak, N.E.; Shimamura, A.; Howlett, N.G. Recent discoveries in the molecular pathogenesis of the inherited bone marrow failure syndrome Fanconi anemia. Blood Rev. 2017, 31, 93-99. [CrossRef]

141. Rickman, K.A.; Lach, F.P.; Abhyankar, A.; Donovan, F.X.; Sanborn, E.M.; Kennedy, J.A.; Sougnez, C.; Gabriel, S.B.; Elemento, O.; Chandrasekharappa, S.C.; et al. Deficiency of UBE2T, the E2 Ubiquitin Ligase Necessary for FANCD2 and FANCI Ubiquitination, Causes FA-T Subtype of Fanconi Anemia. Cell Rep. 2015, 12, 35-41. [CrossRef]

142. Lyakhovich, A.; Surralles, J. FANCD2 depletion sensitizes cancer cells repopulation ability in vitro. Cancer Lett. 2007, 256, 186-195. [CrossRef]

143. Ramaekers, C.H.; van den Beucken, T.; Meng, A.; Kassam, S.; Thoms, J.; Bristow, R.G.; Wouters, B.G. Hypoxia disrupts the Fanconi anemia pathway and sensitizes cells to chemotherapy through regulation of UBE2T. Radiother. Oncol. 2011, 101, 190-197. [CrossRef]

144. Alagpulinsa, D.A.; Kumar, S.; Talluri, S.; Nanjappa, P.; Buon, L.; Chakraborty, C.; Samur, M.K.; Szalat, R.; Shammas, M.A.; Munshi, N.C. Amplification and overexpression of E2 ubiquitin conjugase UBE2T promotes homologous recombination in multiple myeloma. Blood Adv. 2019, 3, 3968-3972. [CrossRef]

145. Tarsounas, M.; Sung, P. The antitumorigenic roles of BRCA1-BARD1 in DNA repair and replication. Nat. Rev. Mol. Cell Biol. 2020, 21, 284-299. [CrossRef] 
146. Kothayer, H.; Spencer, S.M.; Tripathi, K.; Westwell, A.D.; Palle, K. Synthesis and in vitro anticancer evaluation of some 4,6diamino-1,3,5-triazine-2-carbohydrazides as Rad6 ubiquitin conjugating enzyme inhibitors. Bioorg. Med. Chem. Lett. 2016, 26, 2030-2034. [CrossRef] [PubMed]

147. Somasagara, R.R.; Spencer, S.M.; Tripathi, K.; Clark, D.W.; Mani, C.; Madeira da Silva, L.; Scalici, J.; Kothayer, H.; Westwell, A.D.; Rocconi, R.P.; et al. RAD6 promotes DNA repair and stem cell signaling in ovarian cancer and is a promising therapeutic target to prevent and treat acquired chemoresistance. Oncogene 2017, 36, 6680-6690. [CrossRef]

148. Clark, D.W.; Mani, C.; Palle, K. RAD6 promotes chemoresistance in ovarian cancer. Mol. Cell. Oncol. 2018, 5, e1392403. [CrossRef] [PubMed]

149. Hsu, S.H.; Chen, S.H.; Kuo, C.C.; Chang, J.Y. Ubiquitin-conjugating enzyme E2 B regulates the ubiquitination of O(6)methylguanine-DNA methyltransferase and BCNU sensitivity in human nasopharyngeal carcinoma cells. Biochem. Pharmacol. 2018, 158, 327-338. [CrossRef] [PubMed]

150. Yang, H.; Wu, L.; Ke, S.; Wang, W.; Yang, L.; Gao, X.; Fang, H.; Yu, H.; Zhong, Y.; Xie, C.; et al. Downregulation of Ubiquitinconjugating Enzyme UBE2D3 Promotes Telomere Maintenance and Radioresistance of Eca-109 Human Esophageal Carcinoma Cells. J. Cancer 2016, 7, 1152-1162. [CrossRef]

151. Zhou, Y.; Chen, R.; Luo, X.; Zhang, W.D.; Qin, J.J. The E2 ubiquitin-conjugating enzyme UbcH5c: An emerging target in cancer and immune disorders. Drug Discov. Today 2020, 25, 1988-1997. [CrossRef]

152. Lydeard, J.R.; Schulman, B.A.; Harper, J.W. Building and remodelling Cullin-RING E3 ubiquitin ligases. EMBO Rep. 2013, 14, 1050-1061. [CrossRef]

153. Yoon, H.; Kim, M.; Jang, K.; Shin, M.; Besser, A.; Xiao, X.; Zhao, D.; Wander, S.A.; Briegel, K.; Morey, L.; et al. p27 transcriptionally coregulates cJun to drive programs of tumor progression. Proc. Natl. Acad. Sci. USA 2019, 116, 7005-7014. [CrossRef]

154. Mittal, M.K.; Singh, K.; Misra, S.; Chaudhuri, G. SLUG-induced elevation of D1 cyclin in breast cancer cells through the inhibition of its ubiquitination. J. Biol. Chem. 2011, 286, 469-479. [CrossRef] [PubMed]

155. Pierce, N.W.; Lee, J.E.; Liu, X.; Sweredoski, M.J.; Graham, R.L.; Larimore, E.A.; Rome, M.; Zheng, N.; Clurman, B.E.; Hess, S.; et al. Cand1 promotes assembly of new SCF complexes through dynamic exchange of F box proteins. Cell 2013, 153, 206-215. [CrossRef] [PubMed]

156. Walker, A.; Acquaviva, C.; Matsusaka, T.; Koop, L.; Pines, J. UbcH10 has a rate-limiting role in G1 phase but might not act in the spindle checkpoint or as part of an autonomous oscillator. J. Cell Sci. 2008, 121, 2319-2326. [CrossRef]

157. Cai, F.; Chen, P.; Chen, L.; Biskup, E.; Liu, Y.; Chen, P.C.; Chang, J.F.; Jiang, W.; Jing, Y.; Chen, Y.; et al. Human RAD6 promotes G1-S transition and cell proliferation through upregulation of cyclin D1 expression. PLoS ONE 2014, 9, e113727. [CrossRef]

158. Eifler, K.; Vertegaal, A.C.O. SUMOylation-Mediated Regulation of Cell Cycle Progression and Cancer. Trends Biochem. Sci. 2015, 40, 779-793. [CrossRef]

159. Bellail, A.C.; Olson, J.J.; Hao, C. SUMO1 modification stabilizes CDK6 protein and drives the cell cycle and glioblastoma progression. Nat. Commun. 2014, 5, 4234. [CrossRef] [PubMed]

160. Block, K.; Boyer, T.G.; Yew, P.R. Phosphorylation of the human ubiquitin-conjugating enzyme, CDC34, by casein kinase. J. Biol. Chem. 2001, 276, 41049-41058. [CrossRef]

161. Ciliberto, A.; Shah, J.V. A quantitative systems view of the spindle assembly checkpoint. EMBO J. 2009, 28, 2162-2173. [CrossRef]

162. Wild, T.; Larsen, M.S.; Narita, T.; Schou, J.; Nilsson, J.; Choudhary, C. The Spindle Assembly Checkpoint Is Not Essential for Viability of Human Cells with Genetically Lowered APC/C Activity. Cell Rep. 2016, 14, 1829-1840. [CrossRef]

163. Reddy, S.K.; Rape, M.; Margansky, W.A.; Kirschner, M.W. Ubiquitination by the anaphase-promoting complex drives spindle checkpoint inactivation. Nature 2007, 446, 921-925. [CrossRef]

164. Ben-Eliezer, I.; Pomerantz, Y.; Galiani, D.; Nevo, N.; Dekel, N. Appropriate expression of Ube2C and Ube2S controls the progression of the first meiotic division. FASEB J. 2015, 29, 4670-4681. [CrossRef]

165. Hao, Z.; Zhang, H.; Cowell, J. Ubiquitin-conjugating enzyme UBE2C: Molecular biology, role in tumorigenesis, and potential as a biomarker. Tumour. Biol. 2012, 33, 723-730. [CrossRef]

166. Voutsadakis, I.A. Ubiquitin- and ubiquitin-like proteins-conjugating enzymes (E2s) in breast cancer. Mol. Biol. Rep. 2013, 40, 2019-2034. [CrossRef]

167. Bremm, A.; Komander, D. Emerging roles for Lys11-linked polyubiquitin in cellular regulation. Trends. Biochem. Sci. 2011, 36, 355-363. [CrossRef]

168. Saville, M.K.; Sparks, A.; Xirodimas, D.P.; Wardrop, J.; Stevenson, L.F.; Bourdon, J.C.; Woods, Y.L.; Lane, D.P. Regulation of p53 by the ubiquitin-conjugating enzymes UbcH5B/C in vivo. J. Biol. Chem. 2004, 279, 42169-42181. [CrossRef]

169. Wu, M.; Li, X.; Huang, W.; Chen, Y.; Wang, B.; Liu, X. Ubiquitin-conjugating enzyme E2T(UBE2T) promotes colorectal cancer progression by facilitating ubiquitination and degradation of p53. Clin. Res. Hepatol. Gastroenterol. 2020, 101493. [CrossRef]

170. Taylor, W.R.; Stark, G.R. Regulation of the G2/M transition by p53. Oncogene 2001, 20, 1803-1815. [CrossRef] [PubMed]

171. Fokas, E.; O’Neill, E.; Gordon-Weeks, A.; Mukherjee, S.; McKenna, W.G.; Muschel, R.J. Pancreatic ductal adenocarcinoma: From genetics to biology to radiobiology to oncoimmunology and all the way back to the clinic. Biochim. Biophys. Acta 2015, 1855, 61-82. [CrossRef]

172. Pan, Y.H.; Yang, M.; Liu, L.P.; Wu, D.C.; Li, M.Y.; Su, S.G. UBE2S enhances the ubiquitination of p53 and exerts oncogenic activities in hepatocellular carcinoma. Biochem. Biophys. Res. Commun. 2018, 503, 895-902. [CrossRef] 
173. Hong, N.H.; Tak, Y.J.; Rhim, H.; Kang, S. Hip2 ubiquitin-conjugating enzyme has a role in UV-induced G1/S arrest and re-entry. Genes Genom. 2019, 41, 159-166. [CrossRef]

174. Bae, Y.; Jung, S.H.; Kim, G.Y.; Rhim, H.; Kang, S. Hip2 ubiquitin-conjugating enzyme overcomes radiation-induced G2/M arrest. Biochim. Biophys. Acta 2013, 1833, 2911-2921. [CrossRef]

175. Zhang, B.; Deng, C.; Wang, L.; Zhou, F.; Zhang, S.; Kang, W.; Zhan, P.; Chen, J.; Shen, S.; Guo, H.; et al. Upregulation of UBE2Q1 via gene copy number gain in hepatocellular carcinoma promotes cancer progression through $\beta$-catenin-EGFR-PI3K-Akt-mTOR signaling pathway. Mol. Carcinog. 2018, 57, 201-215. [CrossRef]

176. Wang, P.; Li, Y.; Ma, Y.; Zhang, X.; Li, Z.; Yu, W.; Zhu, M.; Wang, J.; Xu, Y.; Xu, A. Comprehensive Investigation into the Role of Ubiquitin-Conjugating Enzyme E2S in Melanoma Development. J. Invest. Dermatol. 2021, 141, 374-384. [CrossRef] [PubMed]

177. Gong, Y.Q.; Peng, D.; Ning, X.H.; Yang, X.Y.; Li, X.S.; Zhou, L.Q.; Guo, Y.L. UBE2T silencing suppresses proliferation and induces cell cycle arrest and apoptosis in bladder cancer cells. Oncol. Lett. 2016, 12, 4485-4492. [CrossRef]

178. Luo, C.; Yao, Y.; Yu, Z.; Zhou, H.; Guo, L.; Zhang, J.; Cao, H.; Zhang, G.; Li, Y.; Jiao, Z. UBE2T knockdown inhibits gastric cancer progression. Oncotarget 2017, 8, 32639-32654. [CrossRef]

179. Palumbo, A., Jr.; Da Costa, N.M.; De Martino, M.; Sepe, R.; Pellecchia, S.; de Sousa, V.P.; Nicolau Neto, P.; Kruel, C.D.; Bergman, A.; Nasciutti, L.E.; et al. UBE2C is overexpressed in ESCC tissues and its abrogation attenuates the malignant phenotype of ESCC cell lines. Oncotarget 2016, 7, 65876-65887. [CrossRef] [PubMed]

180. Nicolau-Neto, P.; Palumbo, A.; De Martino, M.; Esposito, F.; de Almeida Simão, T.; Fusco, A.; Nasciutti, L.E.; Meireles Da Costa, N.; Ribeiro Pinto, L.F. UBE2C Is a Transcriptional Target of the Cell Cycle Regulator FOXM. Genes 2018, 9, 188. [CrossRef] [PubMed]

181. Liu, Y.; Zhao, R.; Chi, S.; Zhang, W.; Xiao, C.; Zhou, X.; Zhao, Y.; Wang, H. UBE2C Is Upregulated by Estrogen and Promotes Epithelial-Mesenchymal Transition via p53 in Endometrial Cancer. Mol. Cancer Res. 2020, 18, 204-215. [CrossRef]

182. Wang, X.; Yin, L.; Yang, L.; Zheng, Y.; Liu, S.; Yang, J.; Cui, H.; Wang, H. Silencing ubiquitin-conjugating enzyme 2C inhibits proliferation and epithelial-mesenchymal transition in pancreatic ductal adenocarcinoma. FEBS J. 2019, 286, 4889-4909. [CrossRef]

183. Huang, P.; Guo, Y.; Zhao, Z.; Ning, W.; Wang, H.; Gu, C.; Zhang, M.; Qu, Y.; Zhang, H.; Song, Y. UBE2T promotes glioblastoma invasion and migration via stabilizing GRP78 and regulating EMT. Aging 2020, 12, 10275-10289. [CrossRef]

184. Bisol, Â.; de Campos, P.S.; Lamers, M.L. Flavonoids as anticancer therapies: A systematic review of clinical trials. Phytother. Res. 2020, 34, 568-582. [CrossRef] [PubMed]

185. Van Cruchten, S.; Van Den Broeck, W. Morphological and biochemical aspects of apoptosis, oncosis and necrosis. Anat. Histol. Embryol. 2002, 31, 214-223. [CrossRef]

186. Jesenberger, V.; Jentsch, S. Deadly encounter: Ubiquitin meets apoptosis. Nat. Rev. Mol. Cell Biol. 2002, 3, 112-121. [CrossRef]

187. Aharinejad, S.; Andrukhova, O.; Lucas, T.; Zuckermann, A.; Wieselthaler, G.; Wolner, E.; Grimm, M. Programmed cell death in idiopathic dilated cardiomyopathy is mediated by suppression of the apoptosis inhibitor Apollon. Ann. Thorac. Surg. 2008, 86, 109-114, discussion 114. [CrossRef]

188. Bartke, T.; Pohl, C.; Pyrowolakis, G.; Jentsch, S. Dual role of BRUCE as an antiapoptotic IAP and a chimeric E2/E3 ubiquitin ligase. Mol. Cell 2004, 14, 801-811. [CrossRef] [PubMed]

189. Hu, T.; Weng, S.; Tang, W.; Xue, R.; Chen, S.; Cai, G.; Cai, Y.; Shen, X.; Zhang, S.; Dong, L. Overexpression of BIRC6 Is a Predictor of Prognosis for Colorectal Cancer. PLoS ONE 2015, 10, e0125281. [CrossRef] [PubMed]

190. Low, C.G.; Luk, I.S.; Lin, D.; Fazli, L.; Yang, K.; Xu, Y.; Gleave, M.; Gout, P.W.; Wang, Y. BIRC6 protein, an inhibitor of apoptosis: Role in survival of human prostate cancer cells. PLoS ONE 2013, 8, e55837. [CrossRef] [PubMed]

191. Dong, X.; Lin, D.; Low, C.; Vucic, E.A.; English, J.C.; Yee, J.; Murray, N.; Lam, W.L.; Ling, V.; Lam, S.; et al. Elevated expression of BIRC6 protein in non-small-cell lung cancers is associated with cancer recurrence and chemoresistance. J. Thorac. Oncol. 2013, 8 , 161-170. [CrossRef]

192. Ismail, E.A.; Mahmoud, H.M.; Tawfik, L.M.; Habashy, D.M.; Adly, A.A.; El-Sherif, N.H.; Abdelwahab, M.A. BIRC6/Apollon gene expression in childhood acute leukemia: Impact on therapeutic response and prognosis. Eur. J. Haematol. 2012, 88, $118-127$. [CrossRef] [PubMed]

193. Luk, S.U.; Xue, H.; Cheng, H.; Lin, D.; Gout, P.W.; Fazli, L.; Collins, C.C.; Gleave, M.E.; Wang, Y. The BIRC6 gene as a novel target for therapy of prostate cancer: Dual targeting of inhibitors of apoptosis. Oncotarget 2014, 5, 6896-6908. [CrossRef] [PubMed]

194. Xu, Y.; Zhang, Z.; Li, J.; Tong, J.; Cao, B.; Taylor, P.; Tang, X.; Wu, D.; Moran, M.F.; Zeng, Y.; et al. The ubiquitin-conjugating enzyme UBE2O modulates c-Maf stability and induces myeloma cell apoptosis. J. Hematol. Oncol. 2017, 10, 132. [CrossRef] [PubMed]

195. Ba, C.; Ni, X.; Yu, J.; Zou, G.; Zhu, H. Ubiquitin conjugating enzyme E2 M promotes apoptosis in osteoarthritis chondrocytes via Wnt/ $\beta$-catenin signaling. Biochem. Biophys. Res. Commun. 2020, 529, 970-976. [CrossRef] [PubMed]

196. Sun, X.X.; Challagundla, K.B.; Dai, M.S. Positive regulation of p53 stability and activity by the deubiquitinating enzyme Otubain. EMBO J. 2012, 31, 576-592. [CrossRef] [PubMed]

197. Ren, J.; Shi, M.; Liu, R.; Yang, Q.H.; Johnson, T.; Skarnes, W.C.; Du, C. The Birc6 (Bruce) gene regulates p53 and the mitochondrial pathway of apoptosis and is essential for mouse embryonic development. Proc. Natl. Acad. Sci. USA 2005, 102, 565-570. [CrossRef]

198. Zhou, C.; Bi, F.; Yuan, J.; Yang, F.; Sun, S. Gain of UBE2D1 facilitates hepatocellular carcinoma progression and is associated with DNA damage caused by continuous IL-6. J. Exp. Clin. Cancer Res. 2018, 37, 290. [CrossRef] 
199. Clevers, H.; Nusse, R. Wnt/ $\beta$-catenin signaling and disease. Cell 2012, 149, 1192-1205. [CrossRef] [PubMed]

200. Schaefer, K.N.; Peifer, M. Wnt/Beta-Catenin Signaling Regulation and a Role for Biomolecular Condensates. Dev. Cell 2019, 48, 429-444. [CrossRef]

201. Li, Z.; Wang, Y.; Li, Y.; Yin, W.; Mo, L.; Qian, X.; Zhang, Y.; Wang, G.; Bu, F.; Zhang, Z.; et al. Ube2s stabilizes $\beta$-Catenin through K11-linked polyubiquitination to promote mesendoderm specification and colorectal cancer development. Cell Death Dis. 2018, 9 , 456. [CrossRef]

202. Shekhar, M.P.; Gerard, B.; Pauley, R.J.; Williams, B.O.; Tait, L. Rad6B is a positive regulator of beta-catenin stabilization. Cancer Res. 2008, 68, 1741-1750. [CrossRef]

203. Shekhar, M.P.; Tait, L.; Gerard, B. Essential role of T-cell factor/beta-catenin in regulation of Rad6B: A potential mechanism for Rad6B overexpression in breast cancer cells. Mol. Cancer Res. 2006, 4, 729-745. [CrossRef]

204. Shin, S.; Im, H.J.; Kwon, Y.J.; Ye, D.J.; Baek, H.S.; Kim, D.; Choi, H.K.; Chun, Y.J. Human steroid sulfatase induces Wnt/ $\beta$-catenin signaling and epithelial-mesenchymal transition by upregulating Twist1 and HIF-1 $\alpha$ in human prostate and cervical cancer cells. Oncotarget 2017, 8, 61604-61617. [CrossRef] [PubMed]

205. Qin, Y.; Du, J.; Fan, C. Ube2S regulates Wnt/ $\beta$-catenin signaling and promotes the progression of non-small cell lung cancer. Int. J. Med. Sci. 2020, 17, 274-279. [CrossRef]

206. Nusse, R.; Clevers, H. Wnt/ $\beta$-Catenin Signaling, Disease, and Emerging Therapeutic Modalities. Cell 2017, 169, 985-999. [CrossRef] [PubMed]

207. Jung, C.R.; Hwang, K.S.; Yoo, J.; Cho, W.K.; Kim, J.M.; Kim, W.H.; Im, D.S. E2-EPF UCP targets pVHL for degradation and associates with tumor growth and metastasis. Nat. Med. 2006, 12, 809-816. [CrossRef] [PubMed]

208. Lin, M.; Lei, T.; Zheng, J.; Chen, S.; Du, L.; Xie, H. UBE2S mediates tumor progression via SOX6/ $\beta$-Catenin signaling in endometrial cancer. Int. J. Biochem. Cell Biol. 2019, 109, 17-22. [CrossRef]

209. Liu, J.; Liu, X. UBE2T silencing inhibited non-small cell lung cancer cell proliferation and invasion by suppressing the wnt/ $\beta$ catenin signaling pathway. Int. J. Clin. Exp. Pathol. 2017, 10, 9482-9488.

210. Hu, W.; Xiao, L.; Cao, C.; Hua, S.; Wu, D. UBE2T promotes nasopharyngeal carcinoma cell proliferation, invasion, and metastasis by activating the AKT/GSK3 $\beta / \beta$-catenin pathway. Oncotarget 2016, 7, 15161-15172. [CrossRef]

211. Deng, L.; Meng, T.; Chen, L.; Wei, W.; Wang, P. The role of ubiquitination in tumorigenesis and targeted drug discovery. Signal. Transduct. Target. Ther. 2020, 5, 11. [CrossRef] [PubMed]

212. Mitchell, S.; Vargas, J.; Hoffmann, A. Signaling via the NFkB system. Wiley Interdiscip. Rev. Syst. Biol. Med. 2016, 8, 227-241. [CrossRef]

213. Magnani, M.; Crinelli, R.; Bianchi, M.; Antonelli, A. The ubiquitin-dependent proteolytic system and other potential targets for the modulation of nuclear factor-kB (NF-kB). Curr. Drug Targets 2000, 1, 387-399. [CrossRef]

214. Wu, X.; Karin, M. Emerging roles of Lys63-linked polyubiquitylation in immune responses. Immunol. Rev. 2015, 266, 161-174. [CrossRef] [PubMed]

215. Varfolomeev, E.; Goncharov, T.; Fedorova, A.V.; Dynek, J.N.; Zobel, K.; Deshayes, K.; Fairbrother, W.J.; Vucic, D. c-IAP1 and c-IAP2 are critical mediators of tumor necrosis factor alpha (TNFalpha)-induced NF-kappaB activation. J. Biol. Chem. 2008, 283, 24295-24299. [CrossRef] [PubMed]

216. Zhou, H.; Wertz, I.; O'Rourke, K.; Ultsch, M.; Seshagiri, S.; Eby, M.; Xiao, W.; Dixit, V.M. Bcl10 activates the NF-kappaB pathway through ubiquitination of NEMO. Nature 2004, 427, 167-171. [CrossRef]

217. Deng, L.; Wang, C.; Spencer, E.; Yang, L.; Braun, A.; You, J.; Slaughter, C.; Pickart, C.; Chen, Z.J. Activation of the IkappaB kinase complex by TRAF6 requires a dimeric ubiquitin-conjugating enzyme complex and a unique polyubiquitin chain. Cell 2000, 103, 351-361. [CrossRef]

218. Shi, C.S.; Kehrl, J.H. Tumor necrosis factor (TNF)-induced germinal center kinase-related (GCKR) and stress-activated protein kinase (SAPK) activation depends upon the E2/E3 complex Ubc13-Uev1A/TNF receptor-associated factor 2 (TRAF2). J. Biol. Chem. 2003, 278, 15429-15434. [CrossRef]

219. Ea, C.K.; Deng, L.; Xia, Z.P.; Pineda, G.; Chen, Z.J. Activation of IKK by TNFalpha requires site-specific ubiquitination of RIP1 and polyubiquitin binding by NEMO. Mol. Cell 2006, 22, 245-257. [CrossRef] [PubMed]

220. Wu, K.; Kovacev, J.; Pan, Z.Q. Priming and extending: A UbcH5/Cdc34 E2 handoff mechanism for polyubiquitination on a SCF substrate. Mol. Cell 2010, 37, 784-796. [CrossRef]

221. Liu, S.; Chen, Z.J. Expanding role of ubiquitination in NF-kB signaling. Cell Res. 2011, 21, 6-21. [CrossRef] [PubMed]

222. Zhang, Y.; Li, Y.; Yang, X.; Wang, J.; Wang, R.; Qian, X.; Zhang, W.; Xiao, W. Uev1A-Ubc13 catalyzes K63-linked ubiquitination of RHBDF2 to promote TACE maturation. Cell. Signal. 2018, 42, 155-164. [CrossRef] [PubMed]

223. Shao, L.; Liu, Y.; Wang, W.; Li, A.; Wan, P.; Liu, W.; Shereen, M.A.; Liu, F.; Zhang, W.; Tan, Q.; et al. SUMO1 SUMOylates and SENP3 deSUMOylates NLRP3 to orchestrate the inflammasome activation. FASEB J. 2020, 34, 1497-1515. [CrossRef] [PubMed]

224. Hoesel, B.; Schmid, J.A. The complexity of NF-kB signaling in inflammation and cancer. Mol. Cancer 2013, 12, 86. [CrossRef] [PubMed]

225. Dolcet, X.; Llobet, D.; Pallares, J.; Matias-Guiu, X. NF-kB in development and progression of human cancer. Virchows Arch. 2005, 446, 475-482. [CrossRef]

226. Prasad, S.; Ravindran, J.; Aggarwal, B.B. NF-kappaB and cancer: How intimate is this relationship. Mol. Cell Biochem. 2010, 336, 25-37. [CrossRef] 
227. Xiao, W.; Lin, S.L.; Broomfield, S.; Chow, B.L.; Wei, Y.F. The products of the yeast MMS2 and two human homologs (hMMS2 and CROC-1) define a structurally and functionally conserved Ubc-like protein family. Nucleic Acids Res. 1998, 26, 3908-3914. [CrossRef]

228. Syed, N.A.; Andersen, P.L.; Warrington, R.C.; Xiao, W. Uev1A, a ubiquitin conjugating enzyme variant, inhibits stress-induced apoptosis through NF-kappaB activation. Apoptosis 2006, 11, 2147-2157. [CrossRef]

229. Wu, Z.; Shen, S.; Zhang, Z.; Zhang, W.; Xiao, W. Ubiquitin-conjugating enzyme complex Uev1A-Ubc13 promotes breast cancer metastasis through nuclear factor- $\mathrm{\kappa B}$ mediated matrix metalloproteinase-1 gene regulation. Breast Cancer Res. 2014, 16, R75. [CrossRef] [PubMed]

230. Dynek, J.N.; Goncharov, T.; Dueber, E.C.; Fedorova, A.V.; Izrael-Tomasevic, A.; Phu, L.; Helgason, E.; Fairbrother, W.J.; Deshayes, K.; Kirkpatrick, D.S.; et al. c-IAP1 and UbcH5 promote K11-linked polyubiquitination of RIP1 in TNF signalling. EMBO J. 2010, 29, 4198-4209. [CrossRef]

231. Ditsworth, D.; Zong, W.X. NF-kappaB: Key mediator of inflammation-associated cancer. Cancer Biol. Ther. 2004, 3, 1214-1216. [CrossRef]

232. Xiong, Y.; Yi, Y.; Wang, Y.; Yang, N.; Rudd, C.E.; Liu, H. Ubc9 Interacts with and SUMOylates the TCR Adaptor SLP-76 for NFAT Transcription in T Cells. J. Immunol. 2019, 203, 3023-3036. [CrossRef]

233. Hattori, K.; Hatakeyama, S.; Shirane, M.; Matsumoto, M.; Nakayama, K. Molecular dissection of the interactions among IkappaBalpha, FWD1, and Skp1 required for ubiquitin-mediated proteolysis of IkappaBalpha. J. Biol. Chem. 1999, 274, 2964129647. [CrossRef] [PubMed]

234. Yamoah, K.; Oashi, T.; Sarikas, A.; Gazdoiu, S.; Osman, R.; Pan, Z.Q. Autoinhibitory regulation of SCF-mediated ubiquitination by human cullin 1's C-terminal tail. Proc. Natl. Acad. Sci. USA 2008, 105, 12230-12235. [CrossRef]

235. Vallabhapurapu, S.; Matsuzawa, A.; Zhang, W.; Tseng, P.H.; Keats, J.J.; Wang, H.; Vignali, D.A.; Bergsagel, P.L.; Karin, M. Nonredundant and complementary functions of TRAF2 and TRAF3 in a ubiquitination cascade that activates NIK-dependent alternative NF-kappaB signaling. Nat. Immunol. 2008, 9, 1364-1370. [CrossRef]

236. Xiao, G.; Harhaj, E.W.; Sun, S.C. NF-kappaB-inducing kinase regulates the processing of NF-kappaB2 p-100. Mol. Cell 2001, 7, 401-409. [CrossRef]

237. Ghosh, S.; May, M.J.; Kopp, E.B. NF-kappa B and Rel proteins: Evolutionarily conserved mediators of immune responses. Annu. Rev. Immunol. 1998, 16, 225-260. [CrossRef]

238. Senftleben, U.; Cao, Y.; Xiao, G.; Greten, F.R.; Krähn, G.; Bonizzi, G.; Chen, Y.; Hu, Y.; Fong, A.; Sun, S.C.; et al. Activation by IKKalpha of a second, evolutionary conserved, NF-kappa B signaling pathway. Science 2001, 293, 1495-1499. [CrossRef] [PubMed]

239. Wu, Z.; Niu, T.; Xiao, W. Uev1A promotes breast cancer cell survival and chemoresistance through the AKT-FOXO1-BIM pathway. Cancer Cell Int. 2019, 19, 331. [CrossRef] [PubMed]

240. Hao, P.; Kang, B.; Li, Y.; Hao, W.; Ma, F. UBE2T promotes proliferation and regulates PI3K/Akt signaling in renal cell carcinoma. Mol. Med. Rep. 2019, 20, 1212-1220. [CrossRef] [PubMed]

241. Duncan, L.M.; Piper, S.; Dodd, R.B.; Saville, M.K.; Sanderson, C.M.; Luzio, J.P.; Lehner, P.J. Lysine-63-linked ubiquitination is required for endolysosomal degradation of class I molecules. EMBO J. 2006, 25, 1635-1645. [CrossRef] [PubMed]

242. Shukla, S.; Allam, U.S.; Ahsan, A.; Chen, G.; Krishnamurthy, P.M.; Marsh, K.; Rumschlag, M.; Shankar, S.; Whitehead, C.; Schipper, M.; et al. KRAS protein stability is regulated through SMURF2: UBCH5 complex-mediated $\beta$-TrCP1 degradation. Neoplasia 2014, 16, 115-128. [CrossRef]

243. Vila, I.K.; Yao, Y.; Kim, G.; Xia, W.; Kim, H.; Kim, S.J.; Park, M.K.; Hwang, J.P.; González-Billalabeitia, E.; Hung, M.C.; et al. A UBE2O-AMPK $\alpha 2$ Axis that Promotes Tumor Initiation and Progression Offers Opportunities for Therapy. Cancer Cell 2017, 31, 208-224. [CrossRef]

244. Wang, L.; Ji, S. Inhibition of Ubc9-Induced CRMP2 SUMOylation Disrupts Glioblastoma Cell Proliferation. J. Mol. Neurosci. 2019, 69, 391-398. [CrossRef]

245. Vij, R.; Wang, M.; Kaufman, J.L.; Lonial, S.; Jakubowiak, A.J.; Stewart, A.K.; Kukreti, V.; Jagannath, S.; McDonagh, K.T.; Alsina, M.; et al. An open-label, single-arm, phase 2 (PX-171-004) study of single-agent carfilzomib in bortezomib-naive patients with relapsed and/or refractory multiple myeloma. Blood 2012, 119, 5661-5670. [CrossRef]

246. Pal, A.; Young, M.A.; Donato, N.J. Emerging potential of therapeutic targeting of ubiquitin-specific proteases in the treatment of cancer. Cancer Res. 2014, 74, 4955-4966. [CrossRef] [PubMed]

247. Hewitt, W.M.; Lountos, G.T.; Zlotkowski, K.; Dahlhauser, S.D.; Saunders, L.B.; Needle, D.; Tropea, J.E.; Zhan, C.; Wei, G.; Ma, B.; et al. Insights into the Allosteric Inhibition of the SUMO E2 Enzyme Ubc9. Angew. Chem. Int. Ed. Engl. 2016, 55, 5703-5707. [CrossRef] [PubMed]

248. Ramatenki, V.; Dumpati, R.; Vadija, R.; Vellanki, S.; Potlapally, S.R.; Rondla, R.; Vuruputuri, U. Targeting the ubiquitin-conjugating enzyme E2D4 for cancer drug discovery-a structure-based approach. J. Chem. Biol. 2017, 10, 51-67. [CrossRef]

249. Wang, L.; Zhang, L. MicroRNAs in amyotrophic lateral sclerosis: From pathogenetic involvement to diagnostic biomarker and therapeutic agent development. Neurol. Sci. 2020, 41, 3569-3577. [CrossRef]

250. Chen, Y.; Gao, D.Y.; Huang, L. In vivo delivery of miRNAs for cancer therapy: Challenges and strategies. Adv. Drug Deliv. Rev. 2015, 81, 128-141. [CrossRef]

251. Sharma, P.; Dando, I.; Strippoli, R.; Kumar, S.; Somoza, A.; Cordani, M.; Tafani, M. Nanomaterials for Autophagy-Related miRNA-34a Delivery in Cancer Treatment. Front. Pharmacol. 2020, 11, 1141. [CrossRef] 
252. Liu, L.; Hua, Y.; Wang, D.; Shan, L.; Zhang, Y.; Zhu, J.; Jin, H.; Li, H.; Hu, Z.; Zhang, W. A sesquiterpene lactone from a medicinal herb inhibits proinflammatory activity of TNF- $\alpha$ by inhibiting ubiquitin-conjugating enzyme UbcH5. Chem. Biol. 2014, 21, 1341-1350. [CrossRef]

253. Chen, H.; Wu, G.; Gao, S.; Guo, R.; Zhao, Z.; Yuan, H.; Liu, S.; Wu, J.; Lu, X.; Yuan, X.; et al. Discovery of Potent Small-Molecule Inhibitors of Ubiquitin-Conjugating Enzyme UbcH5c from $\alpha$-Santonin Derivatives. J. Med. Chem. 2017, 60, 6828-6852. [CrossRef]

254. Xu, Y.; Meng, X. Molecular Simulation Elaborating the Mechanism of $1 \beta$-Hydroxy Alantolactone Inhibiting Ubiquitin-Conjugating Enzyme UbcH5s. Sci. Rep. 2020, 10, 141. [CrossRef]

255. Wang, C.; Shi, G.; Ji, X. Design, synthesis, and anticancer activity evaluation of irreversible allosteric inhibitors of the ubiquitinconjugating enzyme Ube2g2. Med. Chem. Commun. 2018, 9, 1818-1825. [CrossRef]

256. Sanders, M.A.; Brahemi, G.; Nangia-Makker, P.; Balan, V.; Morelli, M.; Kothayer, H.; Westwell, A.D.; Shekhar, M.P.V. Novel inhibitors of Rad6 ubiquitin conjugating enzyme: Design, synthesis, identification, and functional characterization. Mol. Cancer Ther. 2013, 12, 373-383. [CrossRef]

257. Ceccarelli, D.F.; Tang, X.; Pelletier, B.; Orlicky, S.; Xie, W.; Plantevin, V.; Neculai, D.; Chou, Y.C.; Ogunjimi, A.; Al-Hakim, A.; et al. An allosteric inhibitor of the human Cdc34 ubiquitin-conjugating enzyme. Cell 2011, 145, 1075-1087. [CrossRef]

258. Kim, Y.S.; Keyser, S.G.; Schneekloth, J.S., Jr. Synthesis of $2^{\prime}, 3^{\prime}, 4^{\prime}$-trihydroxyflavone (2-D08), an inhibitor of protein sumoylation. Bioorg. Med. Chem. Lett. 2014, 24, 1094-1097. [CrossRef] [PubMed]

259. Zlotkowski, K.; Hewitt, W.M.; Sinniah, R.S.; Tropea, J.E.; Needle, D.; Lountos, G.T.; Barchi, J.J., Jr.; Waugh, D.S.; Schneekloth, J.S., Jr. A Small-Molecule Microarray Approach for the Identification of E2 Enzyme Inhibitors in Ubiquitin-Like Conjugation Pathways. SLAS Discov. 2017, 22, 760-766. [CrossRef] [PubMed]

260. Tsukamoto, S.; Takeuchi, T.; Rotinsulu, H.; Mangindaan, R.E.; van Soest, R.W.; Ukai, K.; Kobayashi, H.; Namikoshi, M.; Ohta, T.; Yokosawa, H. Leucettamol A: A new inhibitor of Ubc13-Uev1A interaction isolated from a marine sponge, Leucetta aff. microrhaphis. Bioorg. Med. Chem. Lett. 2008, 18, 6319-6320. [CrossRef] [PubMed]

261. Ushiyama, S.; Umaoka, H.; Kato, H.; Suwa, Y.; Morioka, H.; Rotinsulu, H.; Losung, F.; Mangindaan, R.E.; de Voogd, N.J.; Yokosawa, H.; et al. Manadosterols A and B, sulfonated sterol dimers inhibiting the Ubc13-Uev1A interaction, isolated from the marine sponge Lissodendryx fibrosa. J. Nat. Prod. 2012, 75, 1495-1499. [CrossRef]

262. Cheng, J.; Fan, Y.H.; Xu, X.; Zhang, H.; Dou, J.; Tang, Y.; Zhong, X.; Rojas, Y.; Yu, Y.; Zhao, Y.; et al. A small-molecule inhibitor of UBE2N induces neuroblastoma cell death via activation of p53 and JNK pathways. Cell Death Dis. 2014, 5, e1079. [CrossRef] [PubMed]

263. Lin, T.H.; Hsu, W.H.; Tsai, P.H.; Huang, Y.T.; Lin, C.W.; Chen, K.C.; Tsai, I.H.; Kandaswami, C.C.; Huang, C.J.; Chang, G.D.; et al. Dietary flavonoids, luteolin and quercetin, inhibit invasion of cervical cancer by reduction of UBE2S through epithelialmesenchymal transition signaling. Food Funct. 2017, 8, 1558-1568. [CrossRef]

264. Cornwell, M.J.; Thomson, G.J.; Coates, J.; Belotserkovskaya, R.; Waddell, I.D.; Jackson, S.P.; Galanty, Y. Small-Molecule Inhibition of UBE2T/FANCL-Mediated Ubiquitylation in the Fanconi Anemia Pathway. ACS Chem. Biol. 2019, 14, 2148-2154. [CrossRef]

265. Jin, D.; Guo, J.; Wu, Y.; Du, J.; Wang, X.; An, J.; Hu, B.; Kong, L.; Di, W.; Wang, W. Retraction of “UBE2C, Directly Targeted by miR-548e-5p, Increases the Cellular Growth and Invasive Abilities of Cancer Cells Interacting with the EMT Marker Protein Zinc Finger E-box Binding Homeobox 1/2 in NSCLC". Theranostics 2020, 10, 9619. [CrossRef] [PubMed]

266. Lu, J.; Gu, X.; Liu, F.; Rui, Z.; Liu, M.; Zhao, L. Antitumor effects of hsa-miR661-3p on non-small cell lung cancer in vivo and in vitro. Oncol. Rep. 2019, 41, 2987-2996. [CrossRef] [PubMed]

267. Hu, J.; Wu, X.; Yang, C.; Rashid, K.; Ma, C.; Hu, M.; Ding, Q.; Jiang, H. Anticancer effect of icaritin on prostate cancer via regulating miR-381-3p and its target gene UBE2C. Cancer Med. 2019, 8, 7833-7845. [CrossRef]

268. Wei, X.; You, X.; Zhang, J.; Zhou, C. MicroRNA-1305 Inhibits the Stemness of LCSCs and Tumorigenesis by Repressing the UBE2T-Dependent Akt-Signaling Pathway. Mol. Ther. Nucleic Acids 2019, 16, 721-732. [CrossRef]

269. Zhao, Z.; Tan, X.; Zhao, A.; Zhu, L.; Yin, B.; Yuan, J.; Qiang, B.; Peng, X. microRNA-214-mediated UBC9 expression in glioma. BMB Rep. 2012, 45, 641-646. [CrossRef] 